\title{
Understanding the hydrogen storage behavior of promising Al-Mg-Na compositions using thermodynamic modeling
}

\author{
S. Abdessameud ${ }^{1} \cdot$ M. Medraj ${ }^{1,2}$
}

Received: 4 August 2015/Accepted: 9 March 2016/Published online: 5 April 2016

(c) The Author(s) 2016. This article is published with open access at Springerlink.com

\begin{abstract}
Thermodynamic modeling of the $\mathrm{Al}-\mathrm{Mg}-\mathrm{Na}-$ $\mathrm{H}$ system is performed in this work to understand the phase relationships and reaction mechanisms in this system. The Al-Na system is reassessed using the modified quasichemical model for the liquid phase. All the terminal solid solutions were remodeled using the compound energy formalism. The thermodynamic properties of the ternary systems are estimated from the models of the binary systems and the ternary compound using the CALPHAD method. The reaction pathways for the systems $\mathrm{MgH}_{2} /$ $\mathrm{AlH}_{3}, \mathrm{MgH}_{2} / \mathrm{NaAlH}_{4}$, and $\mathrm{MgH}_{2} / \mathrm{Na}_{3} \mathrm{AlH}_{6}$ are calculated and compared to the experimental data from the literature. Details about the reaction mechanisms and temperatures, the amount of the products, and their composition are revealed and discussed in this work. The calculations show that in the composites $\mathrm{MgH}_{2} / \mathrm{NaAlH}_{4}$ and $\mathrm{MgH}_{2} / \mathrm{Na}_{3} \mathrm{AlH}_{6}$, the components spontaneously destabilize mutually in specific relative amounts by forming $\mathrm{NaMgH}_{3}$, which may play only a catalytic role on the decomposition of $\left(\mathrm{MgH}_{2}+\mathrm{Al}\right)$ mixture, $\mathrm{NaAlH}_{4}$, or $\mathrm{Na}_{3} \mathrm{AlH}_{6}$. Also, $\mathrm{Al}$ destabilizes $\mathrm{MgH}_{2}$ and $\mathrm{NaMgH}_{3}$ by forming $\beta$ phase and reducing the decomposition temperatures of these hydrides by more than $50{ }^{\circ} \mathrm{C}$. The constructed database is successfully used to reproduce the pressure-composition isotherms (PCIs) for $\mathrm{Mg}-10$ at\% $\mathrm{Al}$ and $\mathrm{Mg}-4 \mathrm{at} \% \mathrm{Al}$ alloys at
\end{abstract}

M. Medraj

mmedraj@encs.concordia.ca

1 Department of Mechanical Engineering, Concordia University, 1455 de Maisonneuve Blvd West, Montreal, QC H3G 1M8, Canada

2 Department of Mechanical and Materials Engineering, Masdar Institute of Science and Technology, Masdar City, Abu Dhabi, United Arab Emirates
$350{ }^{\circ} \mathrm{C}$. The results provide a better understanding of the reaction mechanisms in the PCIs found in the literature concerning the number of plateau pressures and their sloping. It is shown that the first plateau pressure observed during the PCIs of $\mathrm{Al}-\mathrm{Mg}$ alloys depends on $\mathrm{Al}$ content and is higher than that of pure $\mathrm{Mg}$. This difference is due to $\mathrm{Al}$ solubility in hep-Mg.

Keywords Hydrogen storage - Magnesium hydrides . Sodium alanates $\cdot$ Thermodynamic modeling

\section{Introduction}

Hydrogen storage in light metal hydrides is considered as one of the most promising solutions toward a hydrogen economy. Lots of efforts have been devoted in the last few decades to the search of a metal hydride that satisfies all the requirements for the development of hydrogen fuel cells, with potential applications ranging from micro-fuel cells that power portable electronics to mobile applications. Magnesium hydride $\left(\mathrm{MgH}_{2}\right)$ shows a great potential as a hydrogen storage material because of its high hydrogen storage capacities $(7.6 \mathrm{wt} \%)$, reversibility, and low cost [1]. However, it suffers from extremely slow hydriding kinetics and high decomposition temperature [1]. $\mathrm{MgH}_{2}$ is predicted to decompose to hcp- $\mathrm{Mg}$ and $\mathrm{H}_{2}$ at a temperature of $284.73{ }^{\circ} \mathrm{C}$ and ambient pressure [2]. Many studies have shown the possibility of lowering the decomposition temperature of $\mathrm{MgH}_{2}$ and/or improving its hydriding kinetics by mixing with other elements or compounds. Another group of complex metal hydrides, alanates (or aluminohydrides, a family of complex hydrides containing aluminum and hydrogen), have attracted great interest since the work of Bogdanovic [3] who demonstrated the 
Table 1 Optimized model parameters for the different phases in the $\mathrm{Al}-\mathrm{Mg}-\mathrm{Na}-\mathrm{H}$ system $(\mathrm{J} / \mathrm{mole})$

Liquid phase (MQM)

$g_{H(l)}^{0}=74,266.7-26.2456 T+20.7856 T \ln T$

$Z_{\mathrm{MgH}}^{\mathrm{Mg}}=Z_{\mathrm{MgH}}^{\mathrm{H}}=6, \Delta g_{\mathrm{MgH}}^{0}=-18,049.78$

$Z_{\mathrm{NaH}}^{\mathrm{Na}}=Z_{\mathrm{NaH}}^{\mathrm{H}}=6, \Delta g_{\mathrm{NaH}}^{0}=-39,245.92+8.45 T ;$

$\Delta g_{\mathrm{NaH}}^{10}=12,133.6-0.711 T ; \Delta g_{\mathrm{NaH}}^{01}=-66,944+8.368 T$

$Z_{\mathrm{MgNa}}^{\mathrm{Mg}}=4.5, Z_{\mathrm{MgNa}}^{\mathrm{Na}}=6, \Delta g_{\mathrm{MgNa}}^{0}=7,660.0+2.9 T$

$Z_{\mathrm{AlH}}^{\mathrm{Al}}=Z_{\mathrm{AlH}}^{\mathrm{H}}=6, \Delta g_{\mathrm{AlH}}^{0}=-6,516.58-0.544 T$

$Z_{\mathrm{MgAl}}^{\mathrm{Mg}}=Z_{\mathrm{MgAl}}^{\mathrm{Al}}=6, \Delta g_{\mathrm{MgAl}}^{0}=-2761.44+1.52716 T ; \Delta g_{\mathrm{AgAl}}^{10}=481.4+0.6276 T$

$Z_{\mathrm{AlNa}}^{\mathrm{Al}}=Z_{\mathrm{AlNa}}^{\mathrm{Na}}=6, \Delta g_{\mathrm{AlNa}}^{0}=203509.76+5.89944 T ; \Delta g_{\mathrm{AlNa}}^{10}=-193133.44$

This work

Terminal solid solutions (compound energy formalism)

hcp- $(\mathrm{Mg})(\mathrm{Mg}, \mathrm{Na}, \mathrm{Al})_{2}(\mathrm{H}, \mathrm{Va})_{1}$

${ }^{0} G_{\mathrm{Mg} . \mathrm{Va}}^{\mathrm{Mg}_{2}}=2 G\left(\mathrm{Mg}_{\mathrm{hcp}}\right) ;{ }^{0} G_{\mathrm{Na} . \mathrm{Va}}^{\mathrm{Na}_{2}}=2 G\left(\mathrm{Na}_{\mathrm{hcp}}\right) ;{ }^{0} G_{\mathrm{Al} . \mathrm{Va}}^{\mathrm{Al}_{2}}=2 G\left(\mathrm{Al}_{\mathrm{hcp}}\right)$

${ }^{0} G_{\mathrm{Mg} . \mathrm{H}}^{\mathrm{Mg}_{2} \mathrm{H}}=173,217.6-242.672 T+2 G\left(\mathrm{Mg}_{\mathrm{hcp}}\right)+1 / 2\left(\mathrm{H}_{2}\right.$, gas $)$

${ }^{0} G_{\mathrm{Na} . \mathrm{H}}^{\mathrm{Na} \mathrm{H}}=2 G\left(\mathrm{Na}_{\mathrm{hcp}}\right)+1 / 2 G\left(\mathrm{H}_{2}\right.$, gas $) ;{ }^{0} G_{\mathrm{Al}: \mathrm{H}}^{\mathrm{Al}_{2} \mathrm{H}}=100000+2 G\left(\mathrm{Al}_{\mathrm{hcp}}\right)+1 / 2\left(\mathrm{H}_{2}\right.$, gas $)$

${ }^{0} L_{\mathrm{Mg}, \mathrm{Na}: \mathrm{Va}}^{\mathrm{hcp}}=79,496+16.736 T$

${ }^{0} L_{\mathrm{Mg}, \mathrm{Al}: \mathrm{Va}}^{\mathrm{hcp}}=8288.059-8.75 T ;{ }^{1} L_{\mathrm{Mg}, \mathrm{Al}: \mathrm{Va}}^{\mathrm{hcp}}=414.886-6.109 T ;{ }^{0} L_{\mathrm{Al}, \mathrm{Na}: \mathrm{Va}}^{\mathrm{hcp}}=75132$

This work

bcc- $(\mathrm{Na})(\mathrm{Na}, \mathrm{Mg}, \mathrm{Al})_{1}(\mathrm{H}, \mathrm{Va})_{3}$

${ }^{0} G_{\mathrm{Na}: \mathrm{H}}^{\mathrm{NaH}_{3}}=G\left(\mathrm{Na}_{\mathrm{bcc}}\right)+3 / 2 G\left(\mathrm{H}_{2}\right.$, gas $) ;{ }^{0} G_{\mathrm{Mg}: \mathrm{H}}^{\mathrm{MgH}_{3}}=G\left(\mathrm{Mg}_{\mathrm{bcc}}\right)+3 / 2 G\left(\mathrm{H}_{2}, \mathrm{gas}\right) ;$

${ }^{0} G_{\mathrm{Al}: \mathrm{H}}^{\mathrm{AlH}_{3}}=G\left(\mathrm{Al}_{\mathrm{bcc}}\right)+3 / 2 G\left(\mathrm{H}_{2}\right.$, gas $)$

${ }^{0} G_{\mathrm{Na}: \mathrm{Va}}^{\mathrm{Na}}=G\left(\mathrm{Na}_{\mathrm{bcc}}\right) ;{ }^{0} G_{\mathrm{Mg}: \mathrm{Va}}^{\mathrm{Mg}}=G\left(\mathrm{Mg}_{\mathrm{bcc}}\right) ;{ }^{0} G_{\mathrm{Al}: \mathrm{Va}}^{\mathrm{Al}}=G\left(\mathrm{Al}_{\mathrm{bcc}}\right)$

${ }^{0} L_{\mathrm{Na}: \mathrm{H}, \mathrm{Va}}^{\mathrm{bcc}}=-5,569.8 ;{ }^{1} L_{\mathrm{Na}: \mathrm{H}, \mathrm{Va}}^{\mathrm{bcc}}=-2,092.9 ; ;^{0} L_{\mathrm{Na}, \mathrm{Mg}: \mathrm{Va}}^{\mathrm{bcc}}=30,000$

${ }^{0} L_{\mathrm{Al}, \mathrm{Na}: \mathrm{Va}}^{\mathrm{bcc}}=27715$

${ }^{0} L_{\mathrm{Al}, \mathrm{Mg}: \mathrm{Va}}^{\mathrm{bcc}}=5020.8$

fcc-Al $(\mathrm{Al}, \mathrm{Mg}, \mathrm{Na})_{1}(\mathrm{H}, \mathrm{Va})_{1}$

${ }^{0} G_{\mathrm{Al}: \mathrm{Va}}^{\mathrm{Al}}=G\left(\mathrm{Al}_{\mathrm{fcc}}\right) ;{ }^{0} G_{\mathrm{Mg}: \mathrm{Va}}^{\mathrm{Mg}}=G\left(\mathrm{Mg}_{\mathrm{fcc}}\right) ;{ }^{0} G_{\mathrm{Na}: \mathrm{Va}}^{\mathrm{Na}}=G\left(\mathrm{Na}_{\mathrm{fcc}}\right) ;$

${ }^{0} G_{\mathrm{Al}: \mathrm{H}}^{\mathrm{AlH}}=G\left(\mathrm{Al}_{\mathrm{fcc}}\right)+1 / 2 G\left(\mathrm{H}_{2}\right.$, gas $)+100000 ;{ }^{0} G_{\mathrm{Na}: \mathrm{H}}^{\mathrm{NaH}}=G\left(\mathrm{Na}_{\mathrm{fcc}}\right)+1 / 2 G\left(\mathrm{H}_{2}\right.$, gas $)+130 T$

${ }^{0} L_{\mathrm{Al}: \mathrm{H}, \mathrm{Va}}^{\mathrm{fcc}}=-45,805+56.43 T$

${ }^{0} G_{\mathrm{Mg}: \mathrm{H}}^{\mathrm{MgH}}=G\left(\mathrm{Mg}_{\mathrm{fcc}}\right)+1 / 2 G\left(\mathrm{H}_{2}\right.$, gas $)+100000$

${ }^{0} L_{\mathrm{Al}: \mathrm{Mg}, \mathrm{Va}}^{\mathrm{fcc}}=3349.069-1.6763 T ;{ }^{1} L_{\mathrm{Mg}: \mathrm{Al}, \mathrm{Va}}^{\mathrm{fcc}}=169.787-3.05459 T ;{ }^{0} \mathrm{~L}_{\mathrm{Al}: \mathrm{Na}, \mathrm{Va}}^{\mathrm{fcc}}=77741.6 ;{ }^{0} L_{M g, N a: V a}^{f c c}=20000$

Nonstoichiometric compounds [14]

$\gamma\left(\mathrm{Al}_{12} \mathrm{Mg}_{17}\right):(\mathrm{Mg})_{10}(\mathrm{Al}, \mathrm{Mg})_{24}(\mathrm{Al}, \mathrm{Mg})_{24}$ :

$G_{\mathrm{Mg}: \mathrm{Al}: \mathrm{Al}}^{\gamma}=10 G\left(\mathrm{Mg}_{\mathrm{hcp}}\right)+48 G\left(\mathrm{Al}_{\mathrm{fcc}}\right)+178762.96-203 T ; G_{\mathrm{Mg}: \mathrm{Mg}: \mathrm{Al}}^{\gamma}=34 G\left(\mathrm{Mg}_{\mathrm{hcp}}\right)+24 G\left(\mathrm{Al}_{\mathrm{fcc}}\right)-208742+78.474 T$

$G_{\mathrm{Mg}: \mathrm{Al}: \mathrm{Mg}}^{\gamma}=34 G\left(\mathrm{Mg}_{\mathrm{hcp}}\right)+24 G\left(\mathrm{Al}_{\mathrm{hcp}}\right)+359507.2-197.664 T ; G_{\mathrm{Mg}: \mathrm{Mg}: \mathrm{Mg}}^{\gamma}=58 G\left(\mathrm{Mg}_{\mathrm{hcp}}\right)+359153.4-174.58 T$

$\beta\left(\mathrm{A}_{3} \mathrm{Mg}_{2}\right):(\mathrm{Al})_{19}(\mathrm{Al}, \mathrm{Mg})_{2}(\mathrm{Mg})_{12}$

$G_{\mathrm{Al}: \mathrm{Al}: \mathrm{Mg}}^{\beta}=12 G\left(\mathrm{Mg}_{\mathrm{hcp}}\right)+21 G\left(\mathrm{Al}_{\mathrm{fcc}}\right)-82110.6-13.8072 T ; G_{\mathrm{Al}: \mathrm{Mg}: \mathrm{Mg}}^{\beta}=14 G\left(\mathrm{Mg}_{\mathrm{hcp}}\right)+19 G\left(\mathrm{Al}_{\mathrm{fcc}}\right)-72445.56-27.6144 T$

Stoichiometric compounds

$\mathrm{MgH}_{2}: G_{\mathrm{MgH}_{2}}^{0}=-82,842.15+25.42 T-2.87 T \ln T-55.30 \times 10^{-3} T^{2}-34,305.5 T^{-1}$

$\mathrm{NaH}: G_{\mathrm{NaH}}^{0}=-75,767.99+293.72 T-48.69 T \ln T-0.26 \times 10^{-3} T^{2}+1.80 \times 10^{-8} T^{3}+632,658.0 T^{-1}$

$\mathrm{NaMgH}_{3}$ :

$G_{\mathrm{NaMgH}_{3}}=-157,905.82+185.83 T-33.6 T \ln T-61.27 \times 10^{-3} T^{2}$

$\mathrm{AlH}_{3}: G_{\mathrm{AlH}_{3}}=-28,415+213.712933 T-41.75632 T \ln T-14.548469 \times 10^{-3} T^{2}+446400 T^{-1}$

$\varepsilon\left(\mathrm{Al}_{30} \mathrm{Mg}_{23}\right): G_{\varepsilon}=23 G\left(\mathrm{Mg}_{\mathrm{hcp}}\right)+30 G\left(\mathrm{Al}_{\mathrm{fcc}}\right)-116327.71+1673.42 T$

$\mathrm{Al}_{2} \mathrm{Li}_{3}: G_{\mathrm{Al}_{2} \mathrm{Li}_{3}}=2 G\left(\mathrm{Al}_{\mathrm{fcc}}\right)+3 G\left(\mathrm{Li}_{\mathrm{bcc}}\right)-89,690+33.96 T$

This work

$\mathrm{Al}_{4} \mathrm{Li}_{9}: G_{\mathrm{Al}_{4} \mathrm{Li}_{9}}=4 G\left(\mathrm{Al}_{\mathrm{fcc}}\right)+9 G\left(\mathrm{Li}_{\mathrm{bcc}}\right)-438,967.89+69.28 T$

This work 
reversibility of the hydrogenation of the Ti-enhanced alanates. Sodium alanate, $\mathrm{NaAlH}_{4}$, decomposes in two steps with total hydrogen release of $5.6 \mathrm{wt} \%$. According to Qiu et al. [4], it is predicted that, at 1 bar, the first step proceeds at $21.45{ }^{\circ} \mathrm{C}$ and the second one at $106.58{ }^{\circ} \mathrm{C}$. However, research is still needed to improve alanates absorption/ desorption kinetics. Recently, great efforts have been made to investigate hydrogen storage properties and reaction mechanisms in composites containing $\mathrm{MgH}_{2}$ and some complex hydrides such as magnesium and sodium alanates where different explanations have been given about the observed processes [5-11]. However, no theoretical work has been conducted to better understand these experimental results.

In the present work, thermodynamic modeling is used to construct a self-consistent thermodynamic database that describes the Al-Mg-Na-H system and allows the prediction of its hydrogen storage performance and provides a basic understanding of the reaction mechanisms between the different phases in the system under equilibrium conditions. Recently, Abdessameud et al. [2] performed thermodynamic modeling of the $\mathrm{Mg}-\mathrm{Na}-\mathrm{H}$ system and predicted its hydrogen storage properties over a wide range of temperatures and pressures. They [2] proved that the $\mathrm{MgNaH}_{3}$ hydride does not affect the thermodynamics of $\mathrm{MgH}_{2}$ and provided the best working conditions to benefit from its full catalytic role.

\section{Literature review}

This section is composed of two main parts. In the first part, a literature review about the thermodynamic properties and descriptions of the constituent binaries and ternaries in the $\mathrm{Al}-\mathrm{Mg}-\mathrm{Na}-\mathrm{H}$ system is presented. In the second part, the most recent findings about the hydrogen storage properties in the $\mathrm{Al}-\mathrm{Mg}-\mathrm{H}$ and $\mathrm{Al}-\mathrm{Mg}-\mathrm{Na}-\mathrm{H}$ systems are reviewed.

\section{Thermodynamic description of the $\mathrm{Al}-\mathrm{Mg}-\mathrm{Na}-\mathrm{H}$ system}

The $\mathrm{Al}-\mathrm{Mg}-\mathrm{Na}-\mathrm{H}$ system is modeled in the current work using FactSage software [12]. The constituent binary systems are modeled using the modified quasichemical model MQM for the liquid phase and the compound energy formalism for the solid solution phases. These binary systems are either taken from the literature [13-15] or from our previous work [2] or reassessed in the current work (Al$\mathrm{Na}$ ). In many occasions, the models found in the literature were adjusted to suit dealing with hydrogen. This will be elaborated in the following sections. The thermodynamic properties of the ternary systems are estimated from the models of the binary systems and the ternary compounds using the CALPHAD method.

$\mathrm{Mg}-\mathrm{Na}-\mathrm{H}$ system was reviewed and modeled for the first time in our previous work [2]. The constituent binaries $(\mathrm{Mg}-\mathrm{Na}, \mathrm{Mg}-\mathrm{H}$, and $\mathrm{Na}-\mathrm{H})$ were remodeled using the MQM for the liquid phase and three hydrides, $\mathrm{MgH}_{2}, \mathrm{NaH}$, and $\mathrm{MgNaH}_{3}$, were described in this system [2]. The model parameters taken from [2] are used in this work.

\section{The Al-Mg system}

The model parameters used to describe the liquid phase of the $\mathrm{Al}-\mathrm{Mg}$ system are from Harvey [14] who used the MQM to model this phase. In [14], the terminal solid solutions were considered substitutional. Since this system is used for hydrogen storage purposes, the terminal solid solutions are considered interstitial and are adjusted in this work. For the compounds, all the parameters used in [14] are adopted in this work. The phase diagram consists of a liquid phase, terminal fcc- $\mathrm{Al}$ and hcp-Mg solid solutions, and three compounds $\beta\left(\mathrm{Al}_{3} \mathrm{Mg}_{2}\right), \quad \gamma\left(\mathrm{Al}_{12} \mathrm{Mg}_{17}\right)$, and $\varepsilon\left(\mathrm{Al}_{30} \mathrm{Mg}_{23}\right)$.

\section{The Al-H system}

San-Martin and Manchester [16] conducted a critical literature review and assessment of the $\mathrm{Al}-\mathrm{H}$ system. Three stable phases have been reported in the system: liquid, fcc$\mathrm{Al}$ solid solution, and gas. They [16] reported a eutectictype reaction near the melting point of $\mathrm{Al}\left(660.452{ }^{\circ} \mathrm{C}\right)$ and hydrogen solubilities of $1.1 \times 10^{-3}$ and $1.16 \times 10^{-4}$ at $\%$ in liquid $\mathrm{Al}$ and $\mathrm{fcc}-\mathrm{Al}$, respectively. Only one hydride, $\mathrm{AlH}_{3}$, was reported in the literature [17]. $\mathrm{AlH}_{3}$ has a gravimetric density that exceeds $10 \mathrm{wt} \%$ and shows rapid dehydrogenation at low temperatures $\left(<100{ }^{\circ} \mathrm{C}\right)$ with a low heat of reaction (around $-7 \mathrm{~kJ} / \mathrm{molH}_{2}$ ) which makes it a promising hydrogen storage material [17]. According to its thermodynamic properties, $\mathrm{AlH}_{3}$ is metastable at ambient conditions, but its decomposition reaction suffers from poor kinetics [17]. Thus, after the first dehydrogenation, the resulting $\mathrm{Al}$ could be hydrogenated only at high pressure (106 MPa) and $\mathrm{AlH}_{3}$ will not take part in the following hydrogenation/dehydrogenation cycles. Graetz et al. [17] published an extensive review about aluminum hydride as "a hydrogen and energy storage material". Qiu et al. [13] reviewed the existing thermodynamic properties of the $\mathrm{Al}-$ $\mathrm{H}$ system and modeled it. The calculations made by Qiu et al. [13] showed good agreement with experimental data for hydrogen solubility in fcc-Al and thermodynamic properties of $\mathrm{AlH}_{3}$. Later, thermodynamic modeling of hydrogen solubility in liquid $\mathrm{Al}$ was conducted by Harvey and Chartrand [15] using the MQM, showing better agreement with the available experimental data. Since 
MQM is used to describe the liquid phase in this work, the model parameters of Harvey and Chartrand [15] are used to describe the liquid phase in the present work. The model parameters given by Qiu et al. [13] for the AlH3 hydride and fcc-Al phase are also adopted in this work.

\section{The Al-Na system}

The Al-Na system has been extensively reviewed by Murray [18] and Zhang et al. [19]. The Al-Na system has been assessed by Murray [18], Zhang et al. [19], and Qiu et al. [13].

The assessed phase diagram by Murray [18] shows a miscibility gap in the liquid phase, low solubility of $\mathrm{Na}$ in fcc- $\mathrm{Al}$ and of $\mathrm{Al}$ in bcc-Na, and a monotectic reaction: Liquid $1 \rightarrow$ Liquid $2+$ fcc-Al at $\mathrm{Na}$ composition of $0.18 \pm 0.02$ at $\%$.

Because different models are used in this study for the liquid phase (MQM) and for the terminal solid solutions than previous assessments [13, 18, 19], the system is reassessed in the present work. Scheuber et al. [20] conducted solubility measurements of $\mathrm{Na}$ in liquid $\mathrm{Al}$ by heating under hydrogen gas and quenching. It should be noted that their results are uncertain due to hydrogen contamination as pointed out by Murray [18]. Fink et al. [21] carried out direct and differential thermal analysis measurement to investigate $\mathrm{Al}$ liquidus and monotectic reaction in addition to electrical resistivity and metallographic measurements to investigate the $\mathrm{Na}$ solubility in solid Al. They [21] reported a monotectic composition and temperature of 0.18 at\% $\mathrm{Na}$ and $932 \mathrm{~K}$ in addition to a maximum solubility of $\mathrm{Na}$ in fcc-Al of less than 0.003 at\%. Two years later, Ransley and Neufeld [22] reported a lower value for the monotectic composition $(0.14$ at $\% \mathrm{Na}$ occurring at $932 \mathrm{~K}$ ) and more precise value of $\mathrm{Na}$ solubility in solid $\mathrm{Al}(0.0023$ at\% Na). Later, Na solubility in liquid $\mathrm{Al}$ measurements conducted by Hensen et al. [23] showed higher values compared to [20-22] and also increasing Na solubility with decreasing temperature. Two years later, Fellner et al. [24] reported saturated solubility data (of $\mathrm{Na}$ in liquid $\mathrm{Al}$ ) close to the results of [20-22]. The activity of $\mathrm{Na}$ in molten $\mathrm{Al}$ was determined by Dewing [25] at 1293 and $1353 \mathrm{~K}$ and by Brisley and Fray for super purity $\mathrm{Al}[26]$ at $998 \mathrm{~K}$. These data $[25,26]$ are used in the present work.

\section{The Al-Mg-H system}

Rokhlin and Ivanchenko [27] conducted a literature review on the $\mathrm{Al}-\mathrm{Mg}-\mathrm{H}$ system. Harvey et al. [14, 15] reviewed the hydrogen solubility experimental data of $\mathrm{Al}-\mathrm{Mg}$ liquid alloys and used them in assessing this system using the MQM. These authors [14, 15] obtained good agreement with the experimental data from the literature [28-32]. Therefore, their model parameters of the $\mathrm{Al}-\mathrm{Mg}-\mathrm{H}$ liquid are adopted in this work. In the present work, the solubility of hydrogen in $\mathrm{Al}-\mathrm{Mg}$ compounds $\left[\beta\left(\mathrm{Al}_{3} \mathrm{Mg}_{2}\right), \gamma\left(\mathrm{Al}_{12}\right.\right.$ $\left.\mathrm{Mg}_{17}\right)$ and $\left.\varepsilon\left(\mathrm{Al}_{30} \mathrm{Mg}_{23}\right)\right]$ is neglected, because no significant experimental evidence exists for hydrogen solubility in these compounds in the literature [33, 34].

Only one metastable ternary compound, $\mathrm{Mg}\left(\mathrm{AlH}_{4}\right)_{2}$ (with $\mathrm{P}-3 \mathrm{~m} 1$ structure and a gravimetric density of 9.3 $\mathrm{wt} \%$ ), has been reported in the literature [27]. Palumbo et al. [34] investigated the $\mathrm{Al}-\mathrm{Mg}-\mathrm{H}$ system using thermodynamic modeling and ab initio calculations. However, they [34] focused their literature review on magnesium alanate $\mathrm{Mg}\left(\mathrm{AlH}_{4}\right)_{2}$. Thermodynamic description of the $\mathrm{Mg}\left(\mathrm{AlH}_{4}\right)_{2}$ compound has been provided later by Grove et al. [35] and their parameters are used as initial values in the present work.

Decomposition of $\operatorname{Mg}\left(\mathrm{AlH}_{4}\right)_{2}$ has been investigated by different authors such as Mamatha et al. [36] and Varin et al. [37] using DSC and Kim et al. [38] using TG/MS and DSC, and Iosub et al. [39] using XRD, TPD (temperature programmed desorption), and DSC. It has been concluded that magnesium alanate, $\operatorname{Mg}\left(\mathrm{AlH}_{4}\right)_{2}$, decomposes in two steps $[38,40]$ according to the reactions:

$\mathrm{Mg}\left(\mathrm{AlH}_{4}\right)_{2} \rightarrow \mathrm{MgH}_{2}+2 \mathrm{Al}+3 \mathrm{H}_{2}\left(7 \mathrm{wt} \% \mathrm{H}_{2}\right)$,

$\mathrm{MgH}_{2}+2 \mathrm{Al} \rightarrow 1 / 2 \beta+1 / 2 \mathrm{Al}+\mathrm{H}_{2}\left(2.3 \mathrm{wt} \% \mathrm{H}_{2}\right)$.

An enthalpy value of $1.7 \mathrm{~kJ} / \mathrm{mole}$ for reaction 1 has been found by Mamatha et al. [36], while Varin et al. [37] reported a value close to zero. Iosub et al. [39] estimated that the enthalpy of reaction 1 approached $2 \mathrm{~kJ} / \mathrm{mol}$.

\section{The Al-Mg-Na system}

No experimental thermodynamic data and no ternary compound have been reported in the literature for the Al$\mathrm{Mg}-\mathrm{Na}$ system. Thermodynamic modeling of the system was performed by Zhang et al. [19] by combining the constituent binaries. Since MQM is used in this work, thermodynamic description of the system is predicted from extrapolation of the binaries cited in the " $\mathrm{Al}-\mathrm{Mg}$ system" and "Al-Na system" (Al-Mg and $\mathrm{Al}-\mathrm{Na}$ ) and those assessed in our previous paper $(\mathrm{Mg}-\mathrm{Na})$ [2].

\section{The Al-Na-H system}

The Al-Na-H system has been reviewed and modeled by Qiu et al. [4]. Two ternary compounds have been reported in the literature [4], $\mathrm{NaAlH}_{4}$ (with a tetragonal I41/a structure) and $\mathrm{Na}_{3} \mathrm{AlH}_{6}$ which exist in two forms: $\alpha-\mathrm{Na}_{3}$ $\mathrm{AlH}_{6}$ at temperatures lower than $252{ }^{\circ} \mathrm{C}$ (with a 
monoclinic $\mathrm{P} 21 / \mathrm{c}$ structure) and $\beta-\mathrm{Na}_{3} \mathrm{AlH}_{6}$ at temperatures higher than $252{ }^{\circ} \mathrm{C}$ (with cubic $\mathrm{Fm}-3 \mathrm{~m}$ structure). $\mathrm{NaAlH}_{4}$ decomposes in two steps as follows:

$$
\begin{aligned}
\mathrm{NaAlH}_{4} \rightarrow & 1 / 3 \alpha-\mathrm{Na}_{3} \mathrm{AlH}_{6}+2 / 3 \mathrm{Al} \\
& +\mathrm{H}_{2}\left(3.7 \mathrm{wt} \% \mathrm{H}_{2}\right),
\end{aligned}
$$

$\alpha-\mathrm{Na}_{3} \mathrm{AlH}_{6} \rightarrow 3 \mathrm{NaH}+\mathrm{Al}+3 / 2 \mathrm{H}_{2}\left(1.9 \mathrm{wt} \% \mathrm{H}_{2}\right)$.

Using the substitutional solution model, Qiu et al. [4] provided a thermodynamic description of the Al-Na-H liquid. They assessed the two compounds in the system using the CALPHAD approach and first principle calculations. Their parameters [4] are used in this work for the compounds. However, since the MQM is used in the present work, the ternary liquid has been extrapolated from the constituent binaries described in "Thermodynamic description of $\mathrm{Al}-\mathrm{Mg}-\mathrm{Na}-\mathrm{H}$ system”.

\section{Hydrogen storage behavior in the $\mathrm{Al}-\mathrm{Mg}-\mathrm{Na}-\mathrm{H}$ system}

The Al-Mg-H system

Recently, Liu et al. [41] investigated the decomposition reaction of $\mathrm{Mg}\left(\mathrm{AlH}_{4}\right)_{2}$ using TPD, DSC, and XRD. They [41] reported that, after the first exothermic peak, two dehydrogenation overlapping endothermic peaks were observed. XRD measurements at 200,280 , and $320^{\circ} \mathrm{C}$ showed that diffraction peaks of $\mathrm{Al}$ shifted toward lower angles indicating the increase of solubility of $\mathrm{Mg}$ in the $\mathrm{Al}$ phase. According to these authors [41], the overall dehydrogenation reaction proceeds as follows (with the first reaction as exothermic):
Shang et al. [45] showed that the de-hydrogenation of $\mathrm{MgH}_{2}$ is improved when mixed with $\mathrm{Al}$ using mechanical alloying. Zaluska et al. [44] suggested that $\mathrm{Al}$ is involved in hydriding/de-hydriding reactions through the reaction:

$n \mathrm{MgH}_{2}+m \mathrm{Al} \rightarrow \mathrm{Mg}_{n} \mathrm{Al}_{m}+n \mathrm{H}_{2}$.

Andreasen [46] reviewed the hydrogen storage properties of $\mathrm{Al}-\mathrm{Mg}$ alloys and reported that the $\mathrm{Mg}_{n} \mathrm{Al}_{m}$ compound (in reaction (6)) has been found to be mainly the $\beta$-phase.

Liu et al. [10] investigated the effect of $\mathrm{Al}$ on $\mathrm{MgH}_{2}$ destabilization by ball milling mixtures of $\mathrm{MgH}_{2}+\mathrm{AlH}_{3}$ and $\mathrm{MgH}_{2}+\mathrm{Al}$ (Molar ratio 1:1) and using DSC-MS $\left(\mathrm{H}_{2}\right)$ and XRD analysis. They found that when mixed with $\mathrm{AlH}_{3}$, the dehydrogenation temperature of $\mathrm{MgH}_{2}$ is reduced to $55{ }^{\circ} \mathrm{C}$ compared to $\mathrm{MgH}_{2}$ alone, because of the interaction between $\mathrm{MgH}_{2}$ and the oxide-free $\mathrm{Al}$ which was formed from desorption of $\mathrm{AlH}_{3}$. Also, although $\mathrm{AlH}_{3}$ is metastable and will not form after the first desorption reaction, $\mathrm{MgH}_{2}+\mathrm{AlH}_{3}$ mixture showed improved hydrogen desorption/absorption kinetics compared to $\mathrm{MgH}_{2}+\mathrm{Al}$.

Later, Liu et al. [11] investigated the hydrogen desorption properties of $\mathrm{MgH}_{2} / \mathrm{AlH}_{3}$ composites with molar ratios 1:1, 1:0.5, and 1:0.25. These authors found that the onset hydrogen desorption temperature of $\mathrm{MgH}_{2}$ decreases when the amount of $\mathrm{AlH}_{3}$ increases. The DSC and MS- $\mathrm{H}_{2}$ results indicate that the mixtures $\mathrm{MgH}_{2} / \mathrm{AlH}_{3}$ exhibit a two-stage desorption process. The first one has been related to $\mathrm{AlH}_{3}$ decomposition and the second one to the decomposition of $\mathrm{MgH}_{2}$. Liu et al. [11] reported that the second stage is composed of two overlapping (peaks) desorption steps and showed that $\mathrm{MgH}_{2}$ decomposes in two steps. In their work, XRD analysis of $\mathrm{MgH}_{2}+0.25 \mathrm{AlH}_{3}$ was performed on

$$
\begin{aligned}
\operatorname{Mg}\left(\mathrm{AlH}_{4}\right)_{2} \stackrel{125-200^{\circ} \mathrm{C}}{\longrightarrow} & \mathrm{MgH}_{2}+2 \mathrm{Al}+3 \mathrm{H}_{2} \stackrel{250-320^{\circ} \mathrm{C}}{\longrightarrow} 7 / 9 \mathrm{MgH}_{2}+20 / 9 \mathrm{Al}_{0.9} \mathrm{Mg}_{0.1}+29 / 9 \mathrm{H}_{2} \\
& \stackrel{320-440^{\circ} \mathrm{C}}{\longrightarrow} 6 / 9 \mathrm{Al}_{0.9} \mathrm{Mg}_{0.1}+7 / 15 \mathrm{Al}_{3} \mathrm{Mg}_{2}+4 \mathrm{H}_{2}
\end{aligned}
$$

In these equations, Liu et al. [41] referred to fcc- $\mathrm{Al}$ as $\mathrm{Al}_{0.9} \mathrm{Mg}_{0.1}$ by taking into account the value of the maximum solubility of $\mathrm{Mg}$ in fcc- $\mathrm{Al}$ at $320{ }^{\circ} \mathrm{C}$ as 10 at $\%$. After recharging at $120-210{ }^{\circ} \mathrm{C}$ and 100 bar of hydrogen pressure, only $\mathrm{MgH}_{2}$ and $\mathrm{Al}$ were formed [41].

The hydrogenation properties of $\mathrm{Al}-\mathrm{Mg}$ alloys have been widely investigated $[5,6,10,11,42-45]$. It has been found $[42,43]$ that $\beta\left(\mathrm{Al}_{3} \mathrm{Mg}_{2}\right)$ and $\gamma\left(\mathrm{Al}_{12} \mathrm{Mg}_{17}\right)$ phases can be hydrogenated reversibly to form $\left(\mathrm{MgH}_{2}+\mathrm{Al}\right)$ and $\left(\mathrm{MgH}_{2}+\beta\right)$, respectively. samples heated in the same conditions as the DSC-MS measurements at different temperatures. Liu et al. [11] concluded on the basis of DSC analysis and XRD results that desorption of $\mathrm{Mg}-\mathrm{Al}-\mathrm{H}$ alloys proceeds in two steps.

Andreasen [46] summarized the results of pressurecomposition isotherms (PCIs) found in the literature and concluded that the de/hydrogenation of $\mathrm{Al}-\mathrm{Mg}$ alloys is at least a two-step process when the $\beta$ phase is present. Andreasen [46] also noted that, in most of the PCI studies on the $\mathrm{Al}-\mathrm{Mg}$ alloys, the distinction of the plateau 
pressures was difficult and uncertain because of the sloping of the measured curves and concluded that the thermodynamic parameters of the $\mathrm{Al}-\mathrm{Mg}-\mathrm{H}$ alloys calculated from these curves should be verified by more experiments. Tanniru et al. [5] characterized the hydrogenation behavior (in the temperature range of $180-280^{\circ} \mathrm{C}$ ) and PCIs (in the temperature range of $275-400{ }^{\circ} \mathrm{C}$ ) of $\mathrm{Mg}-8$ at $\% \mathrm{Al}$ alloys compared to pure $\mathrm{Mg}$ to investigate the effect of $\mathrm{Al}$ addition on hydrogen storage properties of magnesium hydride. The PCI results showed that only one plateau was observed for $\mathrm{Mg}$ and $\mathrm{Mg}-8$ at\% $\mathrm{Al}$ alloys. However, the equilibrium pressure for hydride formation in $\mathrm{Mg}-8$ at $\% \mathrm{Al}$ alloys was slightly higher compared to pure $\mathrm{Mg}$ and the calculated enthalpy was lower by less than $10 \%$. The higher plateau pressures have been explained by the change of the thermodynamics of hydride formation due to the solubility of $\mathrm{Al}$ in hcp-Mg which, according to these authors [5], reduces the solubility of hydrogen in hcp-Mg. Also, sloped curves showing the rise of pressure with composition after the plateau region of the $\mathrm{Al}-\mathrm{Mg}$ alloys have been observed by Tanniru et al. [5] and attributed to the hydrogenation of $\gamma$ phase (to form $\mathrm{MgH}_{2}$ and $\beta$ ). Later, Tanniru et al. [6] conducted PCI tests at $350{ }^{\circ} \mathrm{C}$ for $\mathrm{Mg}-10$ at $\% \mathrm{Al}$ and $\mathrm{Mg}-4$ at\% $\mathrm{Al}$ alloys. In the PCI experiments of Tanniru et al. [6], the pressure was increased in small steps and sufficient time was allowed for equilibrium to be reached in each step. For this reason, the results obtained by [6] will be compared with the calculations conducted in this work. Samples at different hydrogenation/dehydrogenation steps were analyzed using X-ray diffraction (XRD) and scanning electron microscopy (SEM) to study the microstructure evolution during PCIs. They [6] reported three steps for hydriding of Mg-10 at\% Al alloys corresponding to three plateaus in PCIs at $350{ }^{\circ} \mathrm{C}$. As for pure $\mathrm{Mg}$, the PCI curve at $350{ }^{\circ} \mathrm{C}$ of $\mathrm{Mg}-4$ at $\% \mathrm{Al}$ alloys showed the existence of only the first plateau with a continuous increase of the pressure with the absorbed hydrogen. They [6] attributed the absence of the second and the third plateau for Mg-4 at\% $\mathrm{Al}$ alloys to the small amount of $\gamma$ phase formed at the end of the first plateau. In addition, Tanniru et al. [6] showed that the first plateau pressure increases with $\mathrm{Al}$ content of the samples and attributed this increase to kinetic factors. These results will be discussed and compared with the calculations done in this work in "Al-Mg-H system".

\section{The Al-Mg-Na-H system}

Investigations on hydrogen properties of mixtures of complex hydrides have been subject to many studies [7-9, 40, 47, 48]. Hudson et al. [40] was the first to report that, in the alanate mixture $0.5 \mathrm{Mg}\left(\mathrm{AlH}_{4}\right)_{2}+\mathrm{NaAlH}_{4}$, the dehydriding temperature of $\mathrm{NaAlH}_{4}$ was lowered by $50{ }^{\circ} \mathrm{C}$ and the desorption kinetics was four times faster. Sartori et al. [48] investigated the hydrogen storage properties of the composites $2 \mathrm{MgH}_{2}+\mathrm{NaH}+3 \mathrm{Al}$ hydrided at $80^{\circ} \mathrm{C}$ and 160 bar. They [48] described the decomposition reaction mechanism of the hydrided composite using TPD and XRD experiments. Ismail et al. [7-9] investigated the hydrogen storage properties and the reaction pathways of $\mathrm{MgH}_{2}$ $\mathrm{NaAlH}_{4} \quad(4: 1) / \mathrm{Na}_{3} \mathrm{AlH}_{6}$ (4:1) composites using XRD, thermo-gravimetric analysis, DSC, TPD, and isothermal sorption measurements. Ismail et al. [7] showed that dehydriding kinetics of $\mathrm{MgH}_{2}$ and $\mathrm{NaAlH}_{4}$ were significantly improved when mixed together and reported that these hydrides destabilize mutually. Ismail et al. [9] reported that during the first step of the dehydrogenation reactions of the $\mathrm{MgH}_{2}-\mathrm{Na}_{3} \mathrm{AlH}_{6}$ (4:1) composite where $\mathrm{NaMgH}_{3}, \mathrm{Al}$, and $\mathrm{H}_{2}$ are formed, the decomposition of $\mathrm{Na}_{3} \mathrm{AlH}_{6}$ starts at a temperature $55{ }^{\circ} \mathrm{C}$ lower than the decomposition temperature of the as-milled $\mathrm{Na}_{3} \mathrm{AlH}_{6}$. In the second step, $\mathrm{MgH}_{2}$ reacts with $\mathrm{Al}$ to decompose and to form the $\beta\left(\mathrm{Al}_{3} \mathrm{Mg}_{2}\right)$ phase. The decomposition temperature of $\mathrm{MgH}_{2}$ in the composite is also $55^{\circ} \mathrm{C}$ lower than the decomposition temperature of the as-milled $\mathrm{MgH}_{2}$ [9]. They [9] suggested that the observed thermodynamic and kinetic destabilization is a consequence of the in situ formation of $\beta$ and $\mathrm{NaMgH}_{3}$ phases during the dehydrogenation reactions of the $\mathrm{MgH}_{2}-\mathrm{Na}_{3} \mathrm{AlH}_{6}$ (or $\mathrm{NaAlH}_{4}$ ) (4:1) composites. In this work, the mechanisms of these reactions are discussed based on thermodynamic calculations.

\section{Thermodynamic modeling}

\section{Pure elements}

The Gibbs energy functions of the pure elements ( $\mathrm{Al}, \mathrm{Mg}$, $\mathrm{Na}$ ) and of pure liquids $\mathrm{Al}, \mathrm{Mg}$, and $\mathrm{Na}$ are taken from the compilation of Dinsdale [49]. The Gibbs energy of liquid monatomic hydrogen has been estimated by Ransley and Talbot [50] and is listed in Table 1.

\section{Stoichiometric compounds}

In the $\mathrm{Al}-\mathrm{Mg}-\mathrm{Na}-\mathrm{H}$ system, the compounds $\mathrm{Al}_{30} \mathrm{Mg}_{23}$, $\mathrm{AlH}_{3}, \mathrm{MgH}_{2}, \mathrm{Mg}\left(\mathrm{AlH}_{4}\right)_{2}, \mathrm{NaH}, \mathrm{NaMgH}_{3}, \mathrm{NaAlH}_{4}$, and $\mathrm{Na}_{3} \mathrm{AlH}_{6}$ are considered as stoichiometric compounds. Gibbs energy of a stoichiometric compound depends only on the Gibbs energy of the components and the Gibbs energy of formation, which is optimized using the experimental data ( $\Delta \mathrm{H}$ and $\Delta \mathrm{S}$ of formation) from the literature.

\section{Gas phase}

The Gibbs energies of the gases included in this study, that is, $\mathrm{Al}, \mathrm{Al}_{2}, \mathrm{AlH}, \mathrm{H}, \mathrm{H}_{2}, \mathrm{Mg}, \mathrm{Mg}_{2}, \mathrm{MgH}, \mathrm{Na}, \mathrm{Na}_{2}$, and $\mathrm{NaH}$, 
Fig. 1 Calculated $\mathrm{Al}-\mathrm{Mg}$ phase diagram at 1 bar

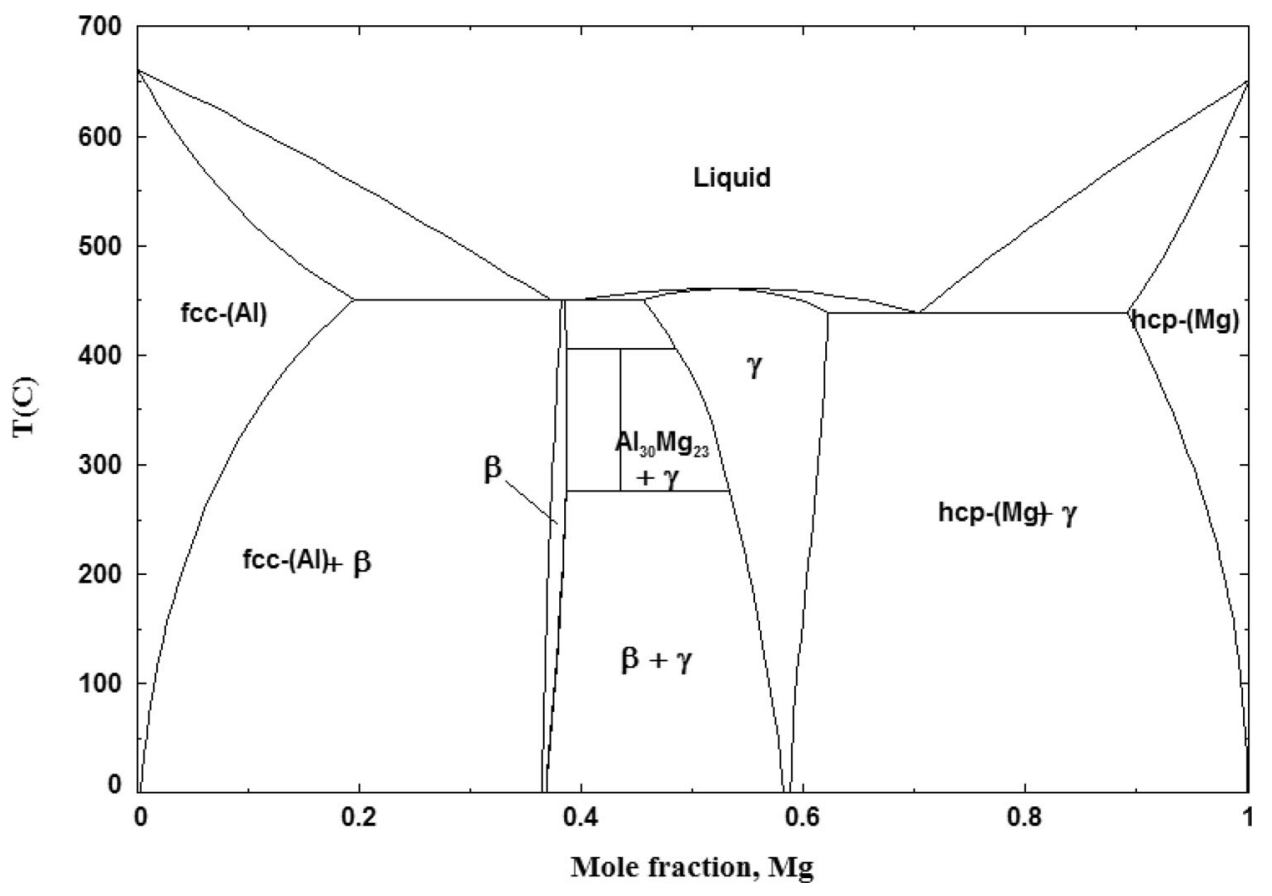

are taken from FactPS database [12]. In the pressure range of interest, the non-ideal contribution of pressure to the Gibbs energy for the gases is very small. In fact, to account for the non-ideal contribution of hydrogen gas, Hemmes et al. [51] calculated the equation of state of hydrogen and other thermodynamic quantities in the range $p \leq 100 \mathrm{GPa}$ and $100 \leq T \leq 1000 \mathrm{~K}$. Numerical values of Gibbs energy and other quantities given in [51] have been used in this work to extrapolate the Gibbs free energy versus temperature of hydrogen gas at 100 bar and used in the calculations for comparison with the ideal gas model. A difference in temperatures of less than $3 \mathrm{~K}$ (at 100 bar) has been found. For this reason, all the gases are considered ideal gases.

\section{Solid solution phase}

Terminal solid solutions are modeled in this work using the compound energy formalism, as hydrogen atoms occupy the interstitial positions in the solid phases fcc-Al, hcp-Mg, and bcc-Na. These phases are described by two sublattices where $\mathrm{Al}, \mathrm{Mg}$, and $\mathrm{Na}$ are mixed randomly in the first sublattice to allow for their mutual solubility. Hydrogen atom and vacancy mix in the second sublattice. Therefore, as discussed in [2], $(\mathrm{Al}, \mathrm{Mg}, \mathrm{Na})_{1}(\mathrm{H}, \mathrm{Va})_{1}$, $(\mathrm{Mg}, \mathrm{Al}, \mathrm{Na})_{2}(\mathrm{H}, \mathrm{Va})_{1}$, and $(\mathrm{Na}, \mathrm{Al}, \mathrm{Mg})_{1}(\mathrm{H}, \mathrm{Va})_{3}$ sublattices are used to model fcc-Al, hcp-Mg, and bcc-Na, respectively.

In the $\mathrm{Al}-\mathrm{Mg}$ system, the compounds $\beta\left(\mathrm{Al}_{3} \mathrm{Mg}_{2}\right)$ and $\gamma$ $\left(\mathrm{Al}_{12} \mathrm{Mg}_{17}\right)$ are taken from Harvey [14] where they are described by the sublattices $(\mathrm{Mg})_{10}(\mathrm{Al}, \mathrm{Mg})_{24}(\mathrm{Al}, \mathrm{Mg})_{24}$ and $(\mathrm{Al})_{19}(\mathrm{Al}, \mathrm{Mg})_{2}(\mathrm{Mg})_{12}$ for $\gamma$ and $\beta$, respectively.

\section{Liquid phases}

The modified quasichemical model (MQM) is used to model the liquid phase for all the binaries. Binary liquid parameters have been interpolated using the asymmetric Kohler-Toop technique where $\mathrm{H}$ is singled out as the asymmetric component as discussed in our previous paper [2]. No ternary parameters have been added to the liquid model.

Thermodynamic equations used to model different phases are explained in our previous paper [2].

\section{Results and discussion}

In "Thermodynamic description of the $\mathrm{Al}-\mathrm{Mg}-\mathrm{Na}-\mathrm{H}$ system", the calculated thermodynamic properties and phase diagrams using the current database are presented for the binary and ternary phases discussed in "Thermodynamic description of $\mathrm{Al}-\mathrm{Mg}-\mathrm{Na}-\mathrm{H}$ system". The thermodynamic parameters used in the present work for the $\mathrm{Al}-$ $\mathrm{Mg}-\mathrm{Na}-\mathrm{H}$ system are given in Table 1 .

In "Hydrogen storage analysis of $\mathrm{Al}-\mathrm{Mg}-\mathrm{Na}-\mathrm{H}$ system using thermodynamic modeling", thermodynamic calculations conducted to analyze and understand the hydrogen storage behavior of the $\mathrm{Al}-\mathrm{Mg}-\mathrm{H}$ and $\mathrm{Al}-\mathrm{Mg}-\mathrm{Na}-\mathrm{H}$ systems are presented in comparison with the experimental 
Fig. 2 Calculated $\mathrm{Al}-\mathrm{H}$ phase diagram (a) and $\mathrm{AlH} 3$ pressure temperature diagram (b)
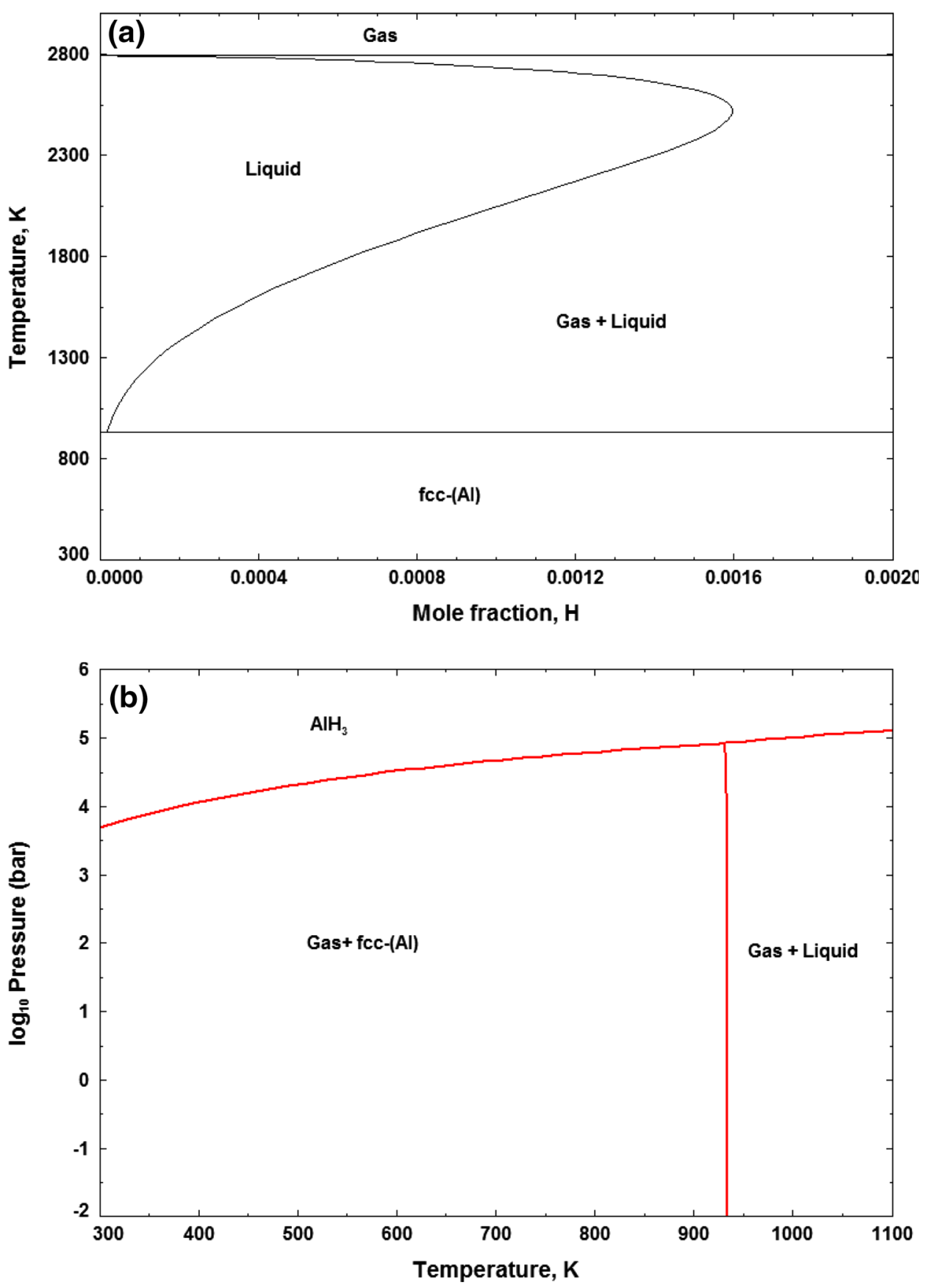

data cited in "Hydrogen storage behavior in Al-Mg-Na-H system".

\section{Thermodynamic description of the Al-Mg-Na-H system}

The Al-Mg and Al-H systems

The calculated $\mathrm{Al}-\mathrm{Mg}$ and $\mathrm{Al}-\mathrm{H}$ phase diagrams at 1 bar are presented in Figs. 1 and 2. Pressure temperature diagram for $\mathrm{AlH}_{3}$ hydride is presented in Fig. 2b. It can be seen that $\mathrm{AlH}_{3}$ is not stable under ambient temperature and pressure conditions.

\section{The Al-Na system}

The model parameters used in the Al-Na system are listed in Table 1. For the liquid phase, the parameters have been determined using the Na solubility in liquid Al [20-24] and $\mathrm{Na}$ activity in liquid $\mathrm{Al}[25,26]$ experimental data. The 
Fig. 3 a The calculated Al-Na phase diagram, $\mathbf{b}$ Al-rich side of Al-Na phase diagram in comparison with experimental data, $\mathbf{c}$ enlarged view of $\mathbf{b}$
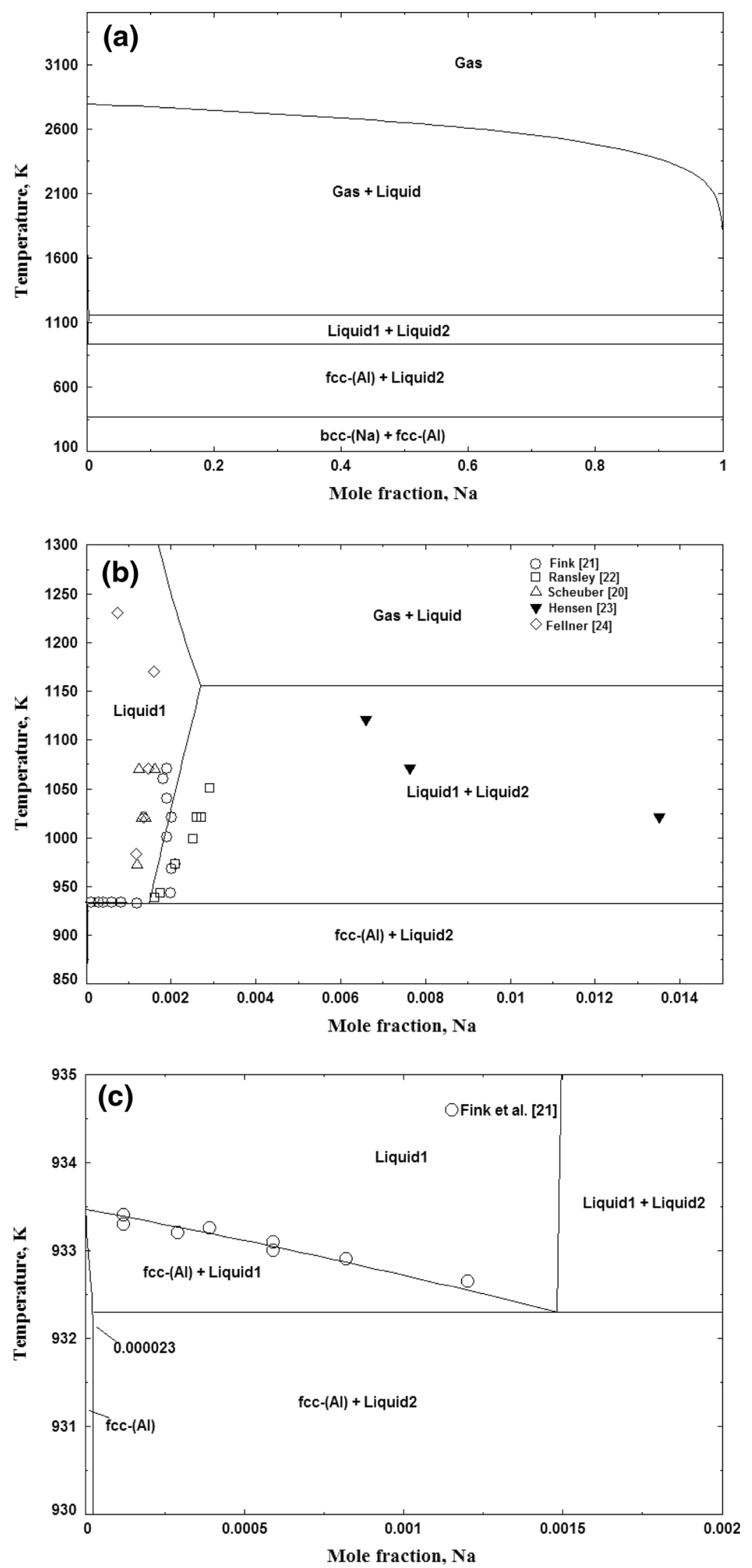
Table 2 Calculated invariant reactions in the Al-Na system in comparison with data from the literature

\begin{tabular}{|c|c|c|c|c|c|}
\hline \multirow{2}{*}{$\frac{\text { Reaction }}{\text { Gas }+ \text { liquid } \rightarrow \text { Liquid } 1+\text { Liquid } 2}$} & \multirow{2}{*}{$\begin{array}{l}\text { Temperature }(\mathrm{K}) \\
1155^{\mathrm{c}}\end{array}$} & \multicolumn{3}{|c|}{$\mathrm{Na}$ concentration (at\%) } & \multirow{2}{*}{$\frac{\text { References }}{\text { This work }}$} \\
\hline & & 100 & 0.27 & 100 & \\
\hline & $1157^{\mathrm{c}}$ & 100 & 0.238 & 100 & [19] \\
\hline \multirow[t]{5}{*}{ Liquid $1+$ Liquid $2 \rightarrow$ fcc-Al + Liquid 2} & $932^{\mathrm{c}}$ & 0.15 & 0.0023 & 100 & This work \\
\hline & $932^{\mathrm{c}}$ & 0.14 & 0.002 & 100 & [19] \\
\hline & $932^{\mathrm{c}}$ & 0.18 & 0.0023 & 100 & [18] \\
\hline & $932^{\mathrm{ex}}$ & 0.18 & $<0.003$ & 100 & {$[21]$} \\
\hline & $932^{\mathrm{ex}}$ & 0.14 & 0.002 & 100 & {$[22]$} \\
\hline \multirow[t]{2}{*}{ fcc-Al + Liquid $2 \rightarrow$ fcc-Al + bcc-Na } & $370.7^{\mathrm{c}}$ & 100 & 0 & 100 & This work \\
\hline & $371^{\mathrm{c}}$ & 99.99 & $7.03 \times 10^{-10}$ & 100 & [19] \\
\hline
\end{tabular}

Fig. 4 The calculated activity of $\mathrm{Na}$ in liquid $\mathrm{Al}-\mathrm{Na}$ in comparison with experimental data

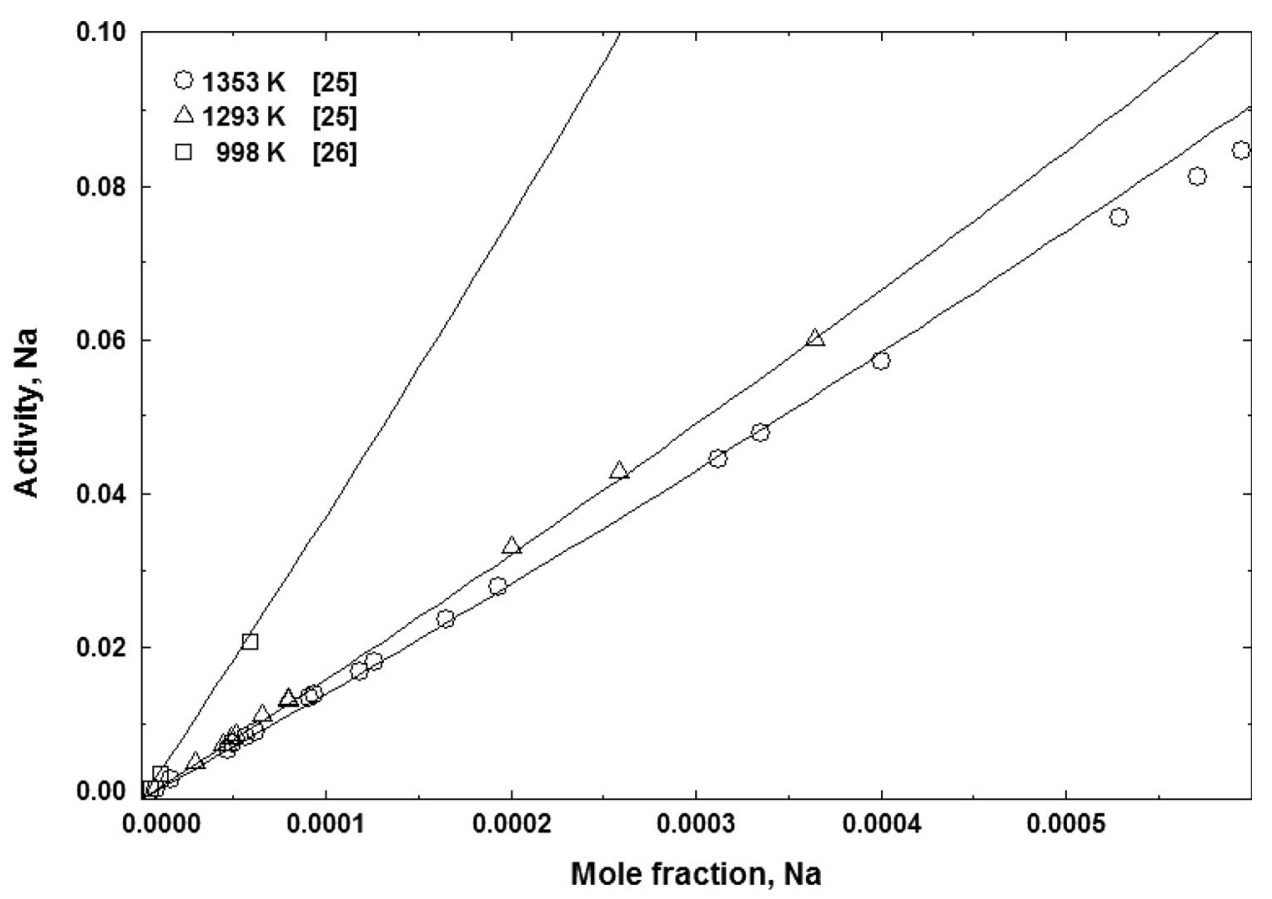

calculated $\mathrm{Al}-\mathrm{Na}$ phase diagram is presented in Fig. 3a. Figure $3 \mathrm{~b}, \mathrm{c}$ gives an enlarged view of the Al-rich part of the calculated phase diagram in comparison with experimental data. The experimental $\mathrm{Na}$ solubility in liquid $\mathrm{Al}$ results reported by Hensen et al. [23] are shown in Fig. 3b for comparison and have not been considered reliable in this work because of their disagreement with all the data reported in the literature. The calculated $\mathrm{Na}$ solubility in liquid $\mathrm{Al}$ shown in Fig. $3 \mathrm{~b}$ are in reasonable agreement with the experimental data, especially those reported by Fink et al. [21]. In fact, as pointed out by Murray [18], the results of Scheuber et al. [20] are not certain due to hydrogen contamination. As can be seen in Fig. 3b, these results [20] are very close to those of Fellner et al. [24]. The experimental data reported by Ransley and Neufeld [22] have been given higher weight by Murray [18] and
Zhang et al. [19] in their assessment of the Al-Na system because of high purity $\mathrm{Al}$ and the experimental procedure used. The calculated phase diagram by Murray fits the phase diagram data of Ransley and Neufeld [22]. However, Murray [18] did not consider recent Na solubility data and $\mathrm{Na}$ activity in liquid Al. The results presented in this work are in reasonable agreement with those of Zhang et al. [19]. The invariant reactions in the Al-Na system in comparison with experimental data and previous calculations are listed in Table 2.

The calculated activities of $\mathrm{Na}$ in $\mathrm{Al}-\mathrm{Na}$ liquid at 1353, 1293 , and $998 \mathrm{~K}$ in comparison with experimental data from the literature are presented in Fig. 4. There is a very good agreement between the calculated activity and the experimental data for $\mathrm{Na}$ concentrations below 0.04 at $\%$. For $\mathrm{Na}$ concentrations above 0.04 at $\%$, the calculated 
Table 3 Thermodynamic properties of formation and decomposition of $\mathrm{Mg}(\mathrm{AlH} 4) 2$

\begin{tabular}{|c|c|c|c|}
\hline RHeaction & Temperature, $\mathrm{K}$ & $\Delta H(\mathrm{~kJ} / \mathrm{mol})$ & References \\
\hline \multirow{4}{*}{$2 \mathrm{Al}+\mathrm{Mg}+4 \mathrm{H}_{2} \rightarrow \mathrm{Mg}\left(\mathrm{AlH}_{4}\right)_{2}$} & 298.15 & -79.1 & This work \\
\hline & 298.15 & $-79.0^{\mathrm{a}}$ & {$[34]$} \\
\hline & 298.15 & -80.33 & {$[53]$} \\
\hline & 298.15 & $-82.8^{\mathrm{a}}$ & {$[35]$} \\
\hline \multirow[t]{6}{*}{$\mathrm{Mg}\left(\mathrm{AlH}_{4}\right)_{2} \rightarrow \mathrm{MgH}_{2}+2 \mathrm{Al}+3 \mathrm{H}_{2}$} & 298.15 & 1.8 & This work \\
\hline & 435 & 1 & {$[34]$} \\
\hline & 423 & 1.7 & {$[36]$} \\
\hline & 435 & 0 & {$[53]$} \\
\hline & $398-423$ & $\sim 0$ & {$[37]$} \\
\hline & 393 & $\sim 2$ & [39] \\
\hline
\end{tabular}

${ }^{\text {a }}$ Calculated using the CALPHAD technique

activities at $1353 \mathrm{~K}$ are higher than the experimental data determined by Dewing [25]. As pointed out by Dewing [52], the experimental procedure (quenching) used in [25] may have been a source of errors.

\section{The $A l-M g-H$ system}

The calculated enthalpy of formation and decomposition of the $\operatorname{Mg}\left(\mathrm{AlH}_{4}\right)_{2}$ are given in Table 3 in comparison with data from the literature.

Good agreement is shown between the calculated heat of formation and decomposition of magnesium alanate and the calculations made by Palumbo et al. [34] and the experimental data of Claudy et al. [53].

The calculated temperature-pressure (PT) diagram for $\mathrm{Mg}\left(\mathrm{AlH}_{4}\right)_{2}$ is given in Fig. 5a. Figure 5b shows the calculated reaction path of $\operatorname{Mg}\left(\mathrm{AlH}_{4}\right)_{2}$ at 1 bar. Figure 5a shows that magnesium alanate is less stable than $\mathrm{AlH}_{3}$ and will not form even at very high pressures. At 1 bar, $\mathrm{Mg}\left(\mathrm{AlH}_{4}\right)_{2}$ decomposes spontaneously to form $\mathrm{MgH}_{2}$, fcc$\mathrm{Al}$, and gas phase. By increasing the temperature, $\mathrm{MgH}_{2}$ decomposes to fcc-Al, $\beta$, and gas phase at $234{ }^{\circ} \mathrm{C}$ following reaction (2) as can be seen in Fig. 5b. These results are in good agreement with the literature. In fact, Palumbo et al. [34] calculated a temperature of $230{ }^{\circ} \mathrm{C}$ for reaction (2), and values in the range $217-240{ }^{\circ} \mathrm{C}$ have been reported using DSC experiments [36-38]. As mentioned in "Al$\mathrm{Mg}-\mathrm{H}$ system", Liu et al. [41] expressed fcc- $\mathrm{Al}$ as $\mathrm{Al}_{0.9-}$ $\mathrm{Mg}_{0.1}$ in Eq. (5) by taking into account the value of the maximum solubility of $\mathrm{Mg}$ in fcc- $\mathrm{Al}$ at $320{ }^{\circ} \mathrm{C}$ as 10 at\%. However, that $\mathrm{MgH}_{2}$ decomposition kinetics was poor during the experiments and $\mathrm{MgH}_{2}$ started to release its hydrogen effectively at around $320{ }^{\circ} \mathrm{C}$ do not indicate clearly that the composition of fcc-Al corresponds to its equilibrium composition at $320{ }^{\circ} \mathrm{C}$.

In Fig. 5b, the different phases are presented with different colors and the $\mathrm{Al}$ and $\mathrm{Mg}$ components of each phase are presented with dotted and dashed lines, respectively, with the same color as the phase. Figure $5 \mathrm{~b}$ shows that the decomposition of $\mathrm{MgH}_{2}$ is preceded by a gradual decrease in the amount of $\mathrm{MgH}_{2}$, caused by its partial gradual decomposition with an increase in the amount of fcc-Al in which the produced $\mathrm{Mg}$ has dissolved.

According to these calculations, the composition of fcc$\mathrm{Al}$ at $234{ }^{\circ} \mathrm{C}$ is $94.89 \% \mathrm{Al}, 5.10 \% \mathrm{Mg}$, and $2.5 \times 10^{-7} \% \mathrm{H}$, which shows that the solubility of hydrogen in fcc- $\mathrm{Al}$ is negligible at this temperature and the solubility of $\mathrm{Mg}$ in fcc- $\mathrm{Al}$ is equal to its solubility limit in the $\mathrm{Al}-\mathrm{Mg}$ system at this temperature (Fig. 1).

The calculated vertical section of the $\mathrm{Al}-\mathrm{Mg}-\mathrm{H}_{2}$ phase diagram at 100 and $230{ }^{\circ} \mathrm{C}$ is presented in Fig. 6. It shows that the composition of the hydrided $\mathrm{Al}-\mathrm{Mg}$ system depends on the hydrogen gas amount added. Above $0.5 \mathrm{~mol}$ fraction $\mathrm{H}_{2}$, the system is composed of gas, fcc-Al, and $\mathrm{MgH}_{2}$ phases in proportions depending on the relative amounts of $\mathrm{Mg}$ and $\mathrm{Al}$.

\section{The Al-Mg-Na system}

There are no experimental data for the $\mathrm{Al}-\mathrm{Mg}-\mathrm{Na}$ ternary system; the calculated isothermal sections at 100 and $500{ }^{\circ} \mathrm{C}$ are presented in Fig. 7. Liquid 2 corresponds to liquid $\mathrm{Na}$ and Liquid 1 to liquid $\mathrm{Al}-\mathrm{Mg}$. Figure 8 shows the calculated vertical section of the $\mathrm{Al}-\mathrm{Mg}-\mathrm{Na}$ system along the composition line AlNa-Mg at 1 bar in comparison with the $\mathrm{Al}-\mathrm{Mg}$ phase diagram (dotted red line). The presented vertical sections reproduce the phase relations and the miscibility gaps in the binary phase diagrams. It can be seen that $\mathrm{Na}$ does not affect the phase relations in the $\mathrm{Al}-\mathrm{Mg}$ phase diagram at 1 bar except the presence of bcc-Na or liquid $\mathrm{Na}$, which shows the limited solubility of $\mathrm{Na}$ in hcp-Mg, fcc-Al, and the Al-Mg compounds. Only a small decrease in the melting point of hcp-Mg is observed when $\mathrm{Na}$ is added to the $\mathrm{Al}-\mathrm{Mg}$ mixture. 
Fig. 5 a P-T diagram and b decomposition reaction path of $\mathrm{Mg}\left(\mathrm{AlH}_{4}\right)_{2}$ at 1 bar
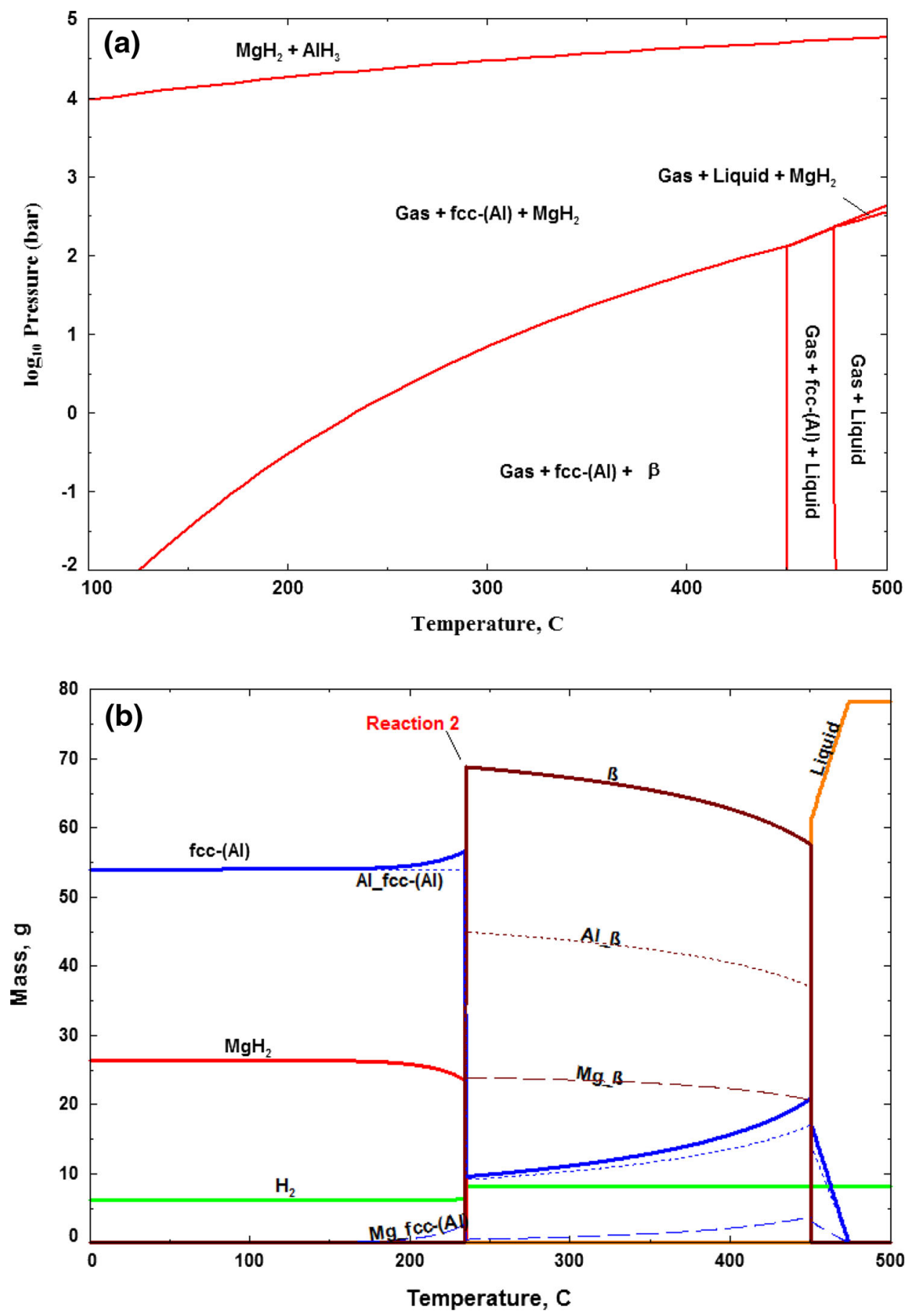

\section{The Al-Na-H system}

The calculated PT diagrams of $\mathrm{NaAlH}_{4}$ is presented in Fig. 9. It shows the evolution of the decomposition temperature of sodium alanates with pressure. $\mathrm{NaAlH}_{4}$ decomposes in two steps following Eqs. 3 and 4 and the decompositions temperatures at 1 bar are 21.45 and $106.58{ }^{\circ} \mathrm{C}$, respectively. At $10 \mathrm{bar}$, these temperatures increase to 81.68 and $179.02{ }^{\circ} \mathrm{C}$ for reactions 3 and 4 , respectively.

The calculated isothermal sections of the $\mathrm{Al}-\mathrm{Na}-\mathrm{H}_{2}$ system at room temperature, at 1 and $10 \mathrm{bar}$, are presented in Fig. 10 to show the phase relations in these conditions.

To show the stability of the hydrides and their decomposition temperatures in this system, vertical sections at different pressures can be calculated using the database 
Fig. 6 The calculated isothermal section of the Al$\mathrm{Mg}-\mathrm{H}_{2}$ phase diagram at $100{ }^{\circ} \mathrm{C}$ (in red) and $230{ }^{\circ} \mathrm{C}$ (in blue)

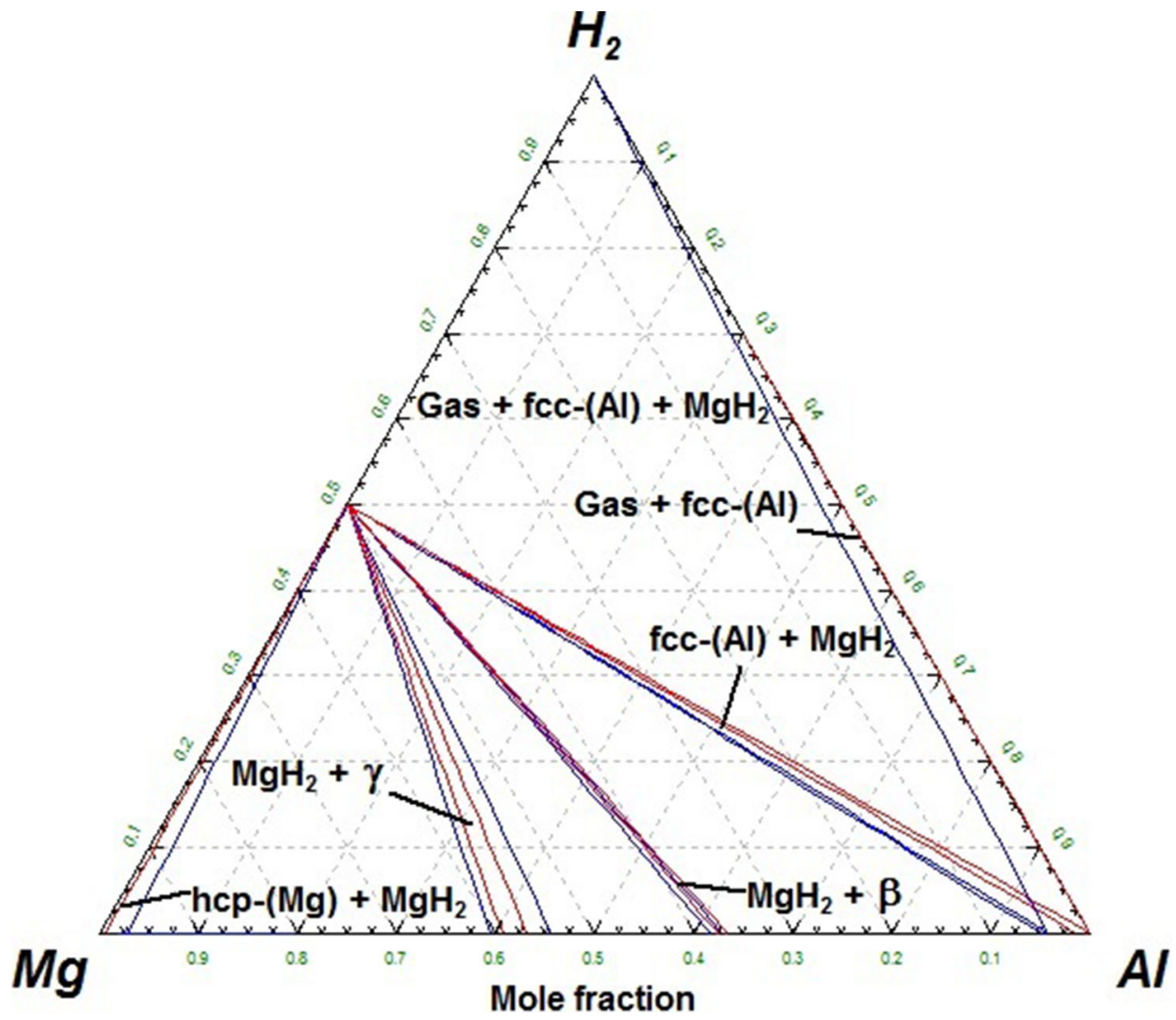

developed in this work. As an example, the calculated vertical sections along the composition line $\mathrm{AlH}_{3}-\mathrm{NaH}$ at 1 and 10 bar are shown in Fig. 11.

\section{Hydrogen storage analysis of the Al-Mg-Na-H system using thermodynamic modeling}

The Al-Mg-H system

The calculated phase diagram of $\mathrm{MgH}_{2}+\mathrm{AlH}_{3}$ at 1 bar is presented in Fig. 12a. An enlarged view of the $\mathrm{MgH}_{2}$-rich part of $\mathrm{MgH}_{2}-\mathrm{AlH}_{3}$ phase diagram is presented in Fig. 12b. It can be seen that the $\mathrm{MgH}_{2}$ decomposition process depends on $\mathrm{Al}$ content. Five regions are identified in Fig. 12a separated by blue dotted lines. For the $\mathrm{AlH}_{3}$ mole fraction below 0.045 , the decomposition of $\mathrm{MgH}_{2}$ occurs in four steps according to the following reactions (the third and the fourth steps can be seen in Fig. 12b):
The decomposition temperature of the last reaction in Eq. (7) varies from $284.73{ }^{\circ} \mathrm{C}$ for pure $\mathrm{MgH}_{2}$ to $283.3^{\circ} \mathrm{C}$ for 0.045 mol fraction of $\mathrm{Al}$ as can be seen in Fig. $12 \mathrm{~b}$. This small difference can be explained by the solubility of Al in hep-Mg.

For $\mathrm{AlH}_{3}$ between 0.045 and 0.46 mol fraction, $\mathrm{MgH}_{2}$ decomposes in three steps. For $\mathrm{AlH}_{3}$ between 0.46 and 0.63 mol fraction, decomposition proceeds in two steps. For AlH3 content between 0.63 and 0.95 mol fraction, $\mathrm{MgH}_{2}$ decomposes in only one step at $234{ }^{\circ} \mathrm{C}$. It should be noted that, for $\mathrm{AlH}_{3}$ content starting from the $0.95 \mathrm{~mol}$ fraction, the decomposition temperature of $\mathrm{MgH}_{2}$ decreases with increasing Al content.

The predicted reactions in the system are compared with the results of Liu et al. [10] on the dehydrogenation process of the $\mathrm{MgH}_{2}+\mathrm{AlH}_{3}$ mixture. This composition corresponds to 0.5 mol fraction of $\mathrm{AlH}_{3}$ in Fig. 12a where it is marked by a red dotted line.

$$
\begin{aligned}
\mathrm{MgH}_{2}+\mathrm{fcc}-\mathrm{Al} \stackrel{234^{\circ} \mathrm{C}}{\longrightarrow} \mathrm{MgH}_{2}+\beta+\mathrm{H}_{2} \stackrel{257.8^{\circ} \mathrm{C}}{\longrightarrow} \mathrm{MgH}_{2}+\gamma+\mathrm{H}_{2} \stackrel{283.3^{\circ} \mathrm{C}}{\longrightarrow} \mathrm{MgH}_{2}+\text { hcp }-\mathrm{Mg}+\mathrm{H}_{2} \\
\stackrel{284.7<\mathrm{T}^{\circ} \mathrm{C}<283.3}{\longrightarrow} \text { hcp }-\mathrm{Mg}+\mathrm{H}_{2}
\end{aligned}
$$


Fig. 7 The calculated Al-Mg$\mathrm{Na}$ isothermal sections at $1 \mathrm{bar}$ and a $100{ }^{\circ} \mathrm{C}$ and b $500{ }^{\circ} \mathrm{C}$

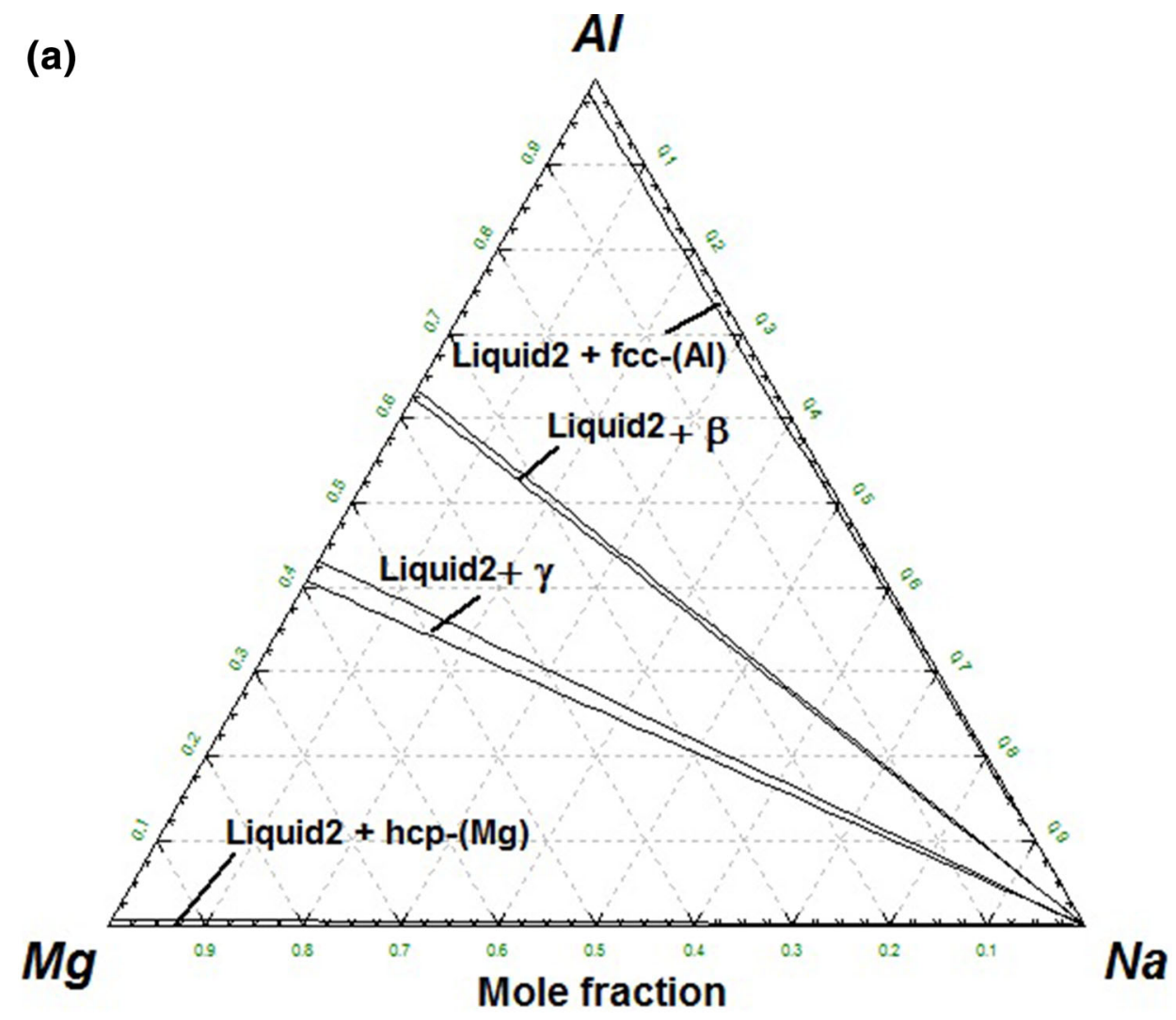

(b)

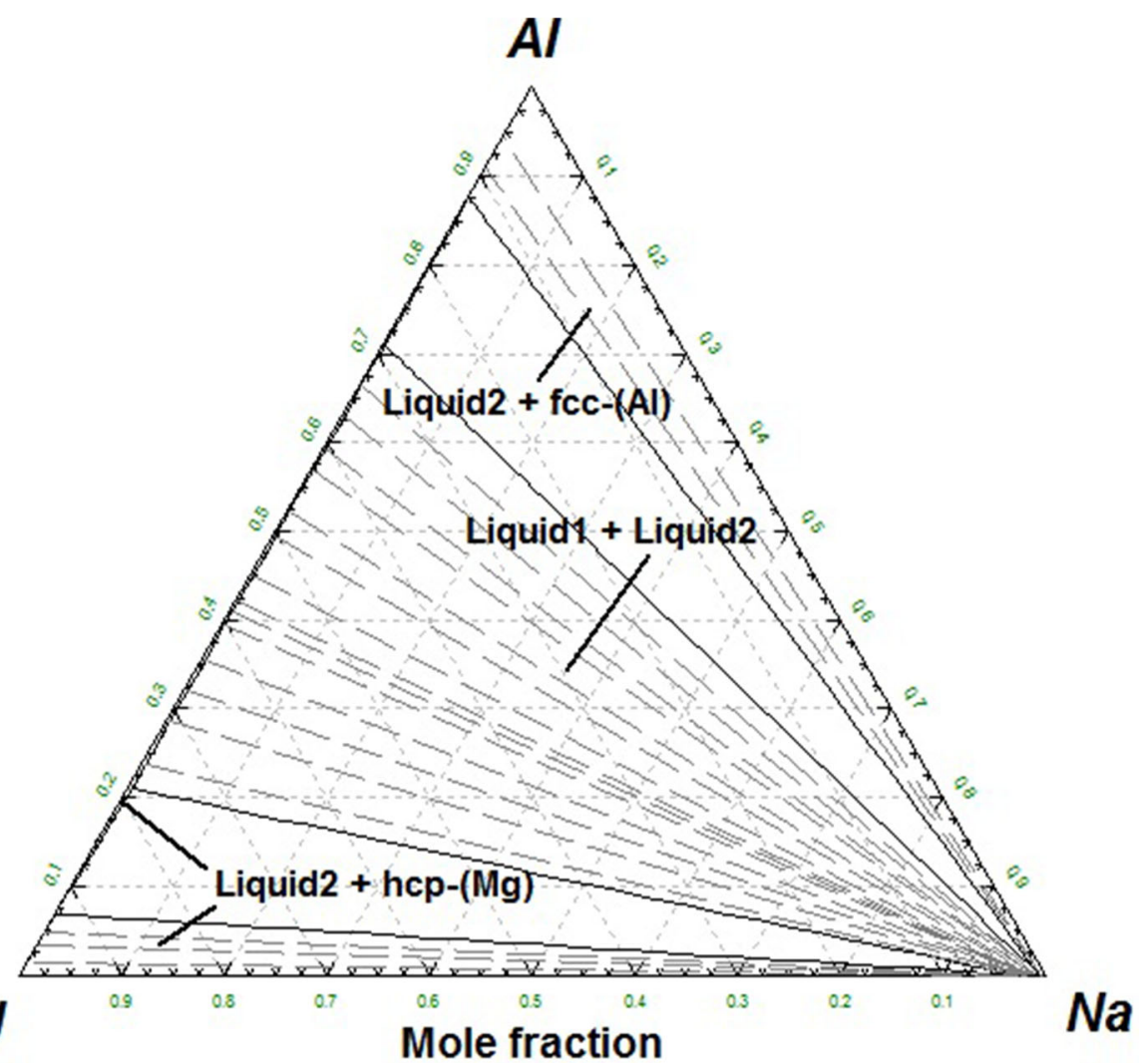


Fig. 8 Calculated vertical section of the $\mathrm{Al}-\mathrm{Mg}-\mathrm{Na}$ system along the composition line $\mathrm{AlNa}-\mathrm{Mg}$ compared to the calculated $\mathrm{Al}-\mathrm{Mg}$ phase diagram (dashed line) at 1 bar
Fig. 9 P-T diagram of $\mathrm{NaAlH}_{4}$

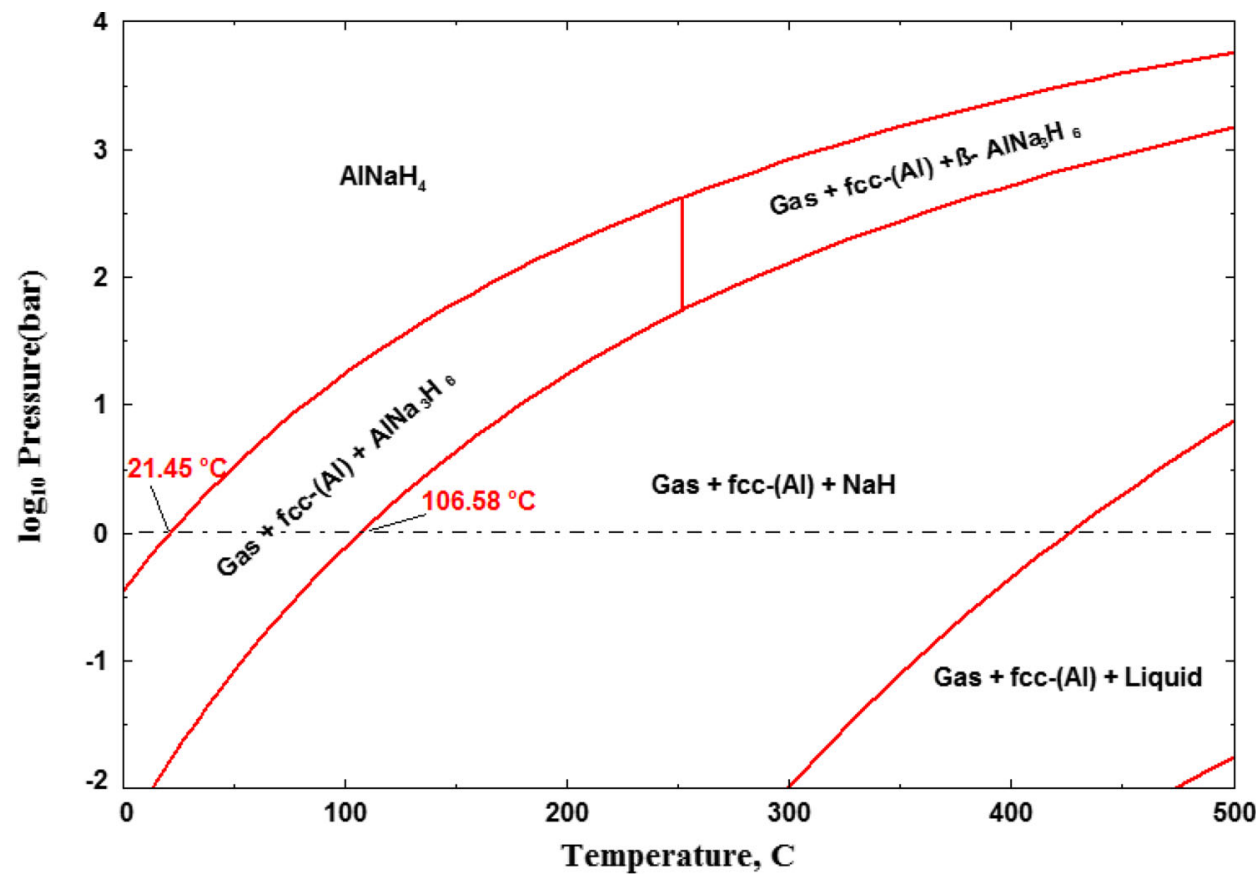

First, Liu et al. [10] reported that the decomposition temperature of $\mathrm{MgH}_{2}$ in the mixture is reduced by $55^{\circ} \mathrm{C}$ compared to the pure $\mathrm{MgH}_{2}$ and attributed this decrease to the interaction between $\mathrm{MgH}_{2}$ and Al. According to our previous paper [2], the theoretical decomposition temperature of $\mathrm{MgH}_{2}$ is $284.73,50.73{ }^{\circ} \mathrm{C}$ higher than the calculated first decomposition step in this mixture $\left(234{ }^{\circ} \mathrm{C}\right)$, which is consistent with the results of Liu et al. [10]. However, the temperatures they [10] reported were higher as a result of the slow kinetics and the long time required to reach equilibrium [10]. Temperatures in the ranges 217-250 ${ }^{\circ} \mathrm{C}$ (DSC) $[36,37]$ and $210-220{ }^{\circ} \mathrm{C}$ (in situ XRD) [36] have also been reported.

In their second investigation on the thermal decomposition of $\mathrm{MgH}_{2} / \mathrm{AlH}_{3}$ composites, Liu et al. [11], using DSC and MS- $\left(\mathrm{H}_{2}\right)$, found that the onset and peak temperatures of the first decomposition of $\mathrm{MgH}_{2}$ in the mixtures decrease with increase in the amount of $\mathrm{AlH}_{3}$. The onset 
Fig. 10 The calculated Al-Na$\mathrm{H}_{2}$ isothermal section at $25{ }^{\circ} \mathrm{C}$ and $\mathbf{a} 1$ bar and $\mathbf{b} 10$ bar

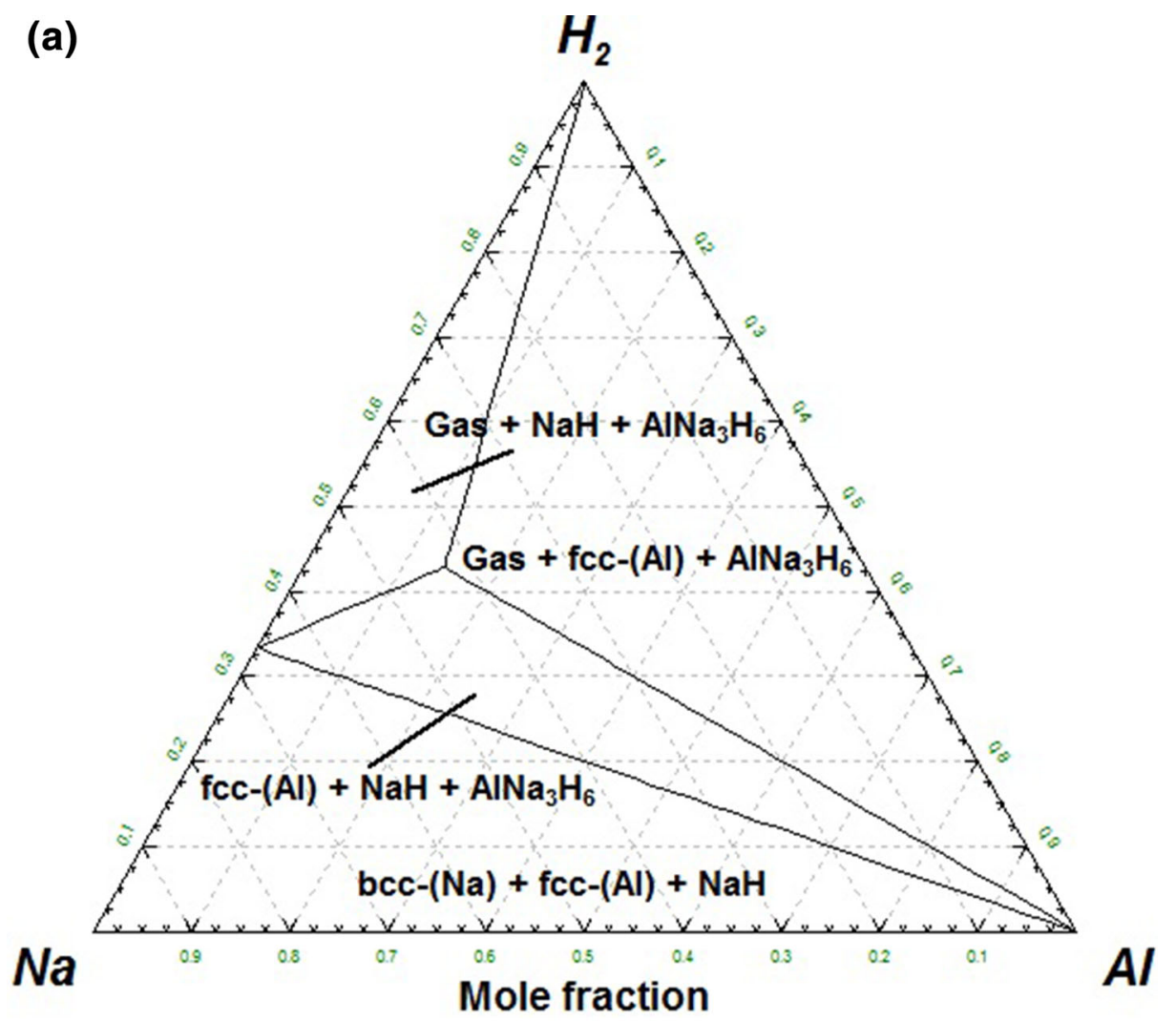

(b)

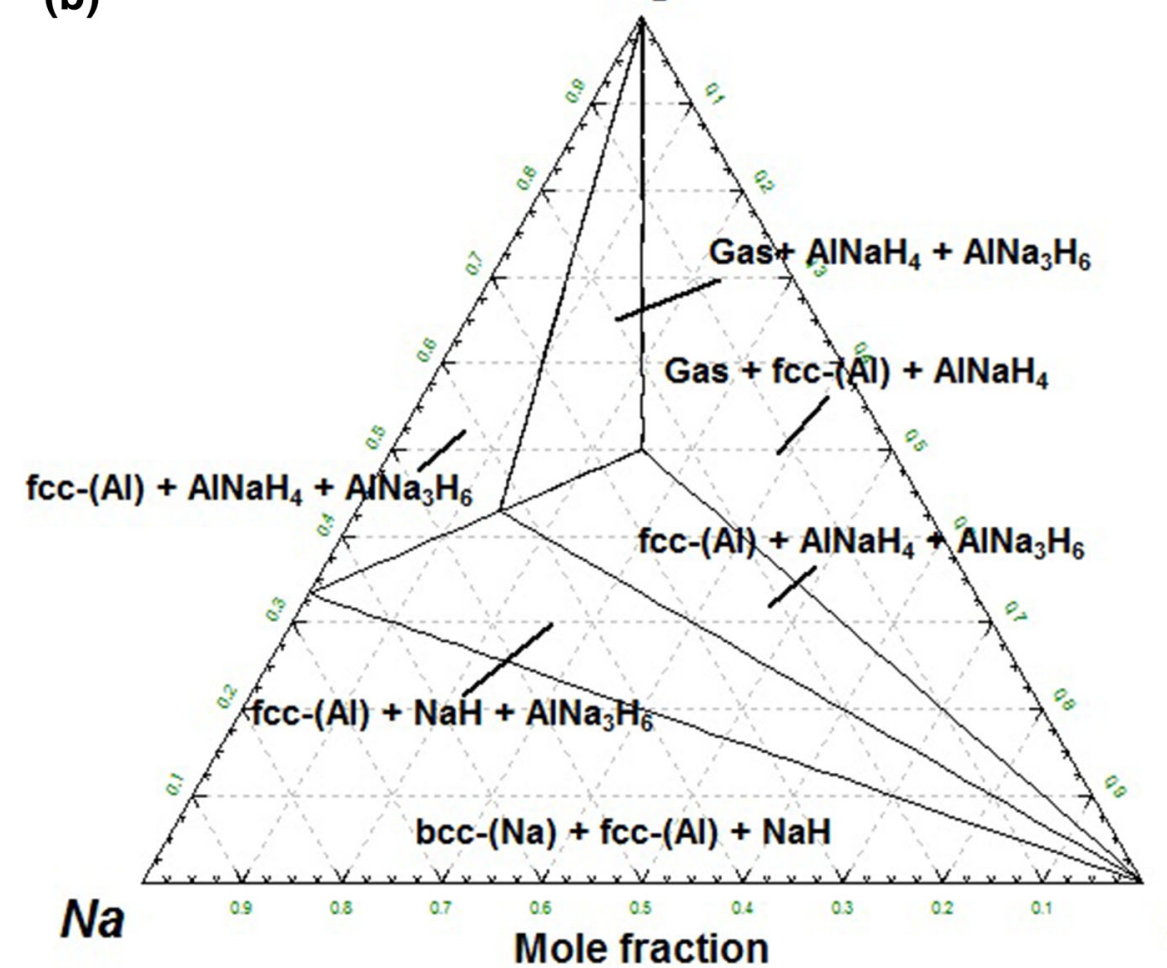


Fig. 11 The calculated $\mathrm{AlH}_{3}-$ $\mathrm{NaH}$ vertical section at a $1 \mathrm{bar}$ and $\mathbf{b} 10 \mathrm{bar}$
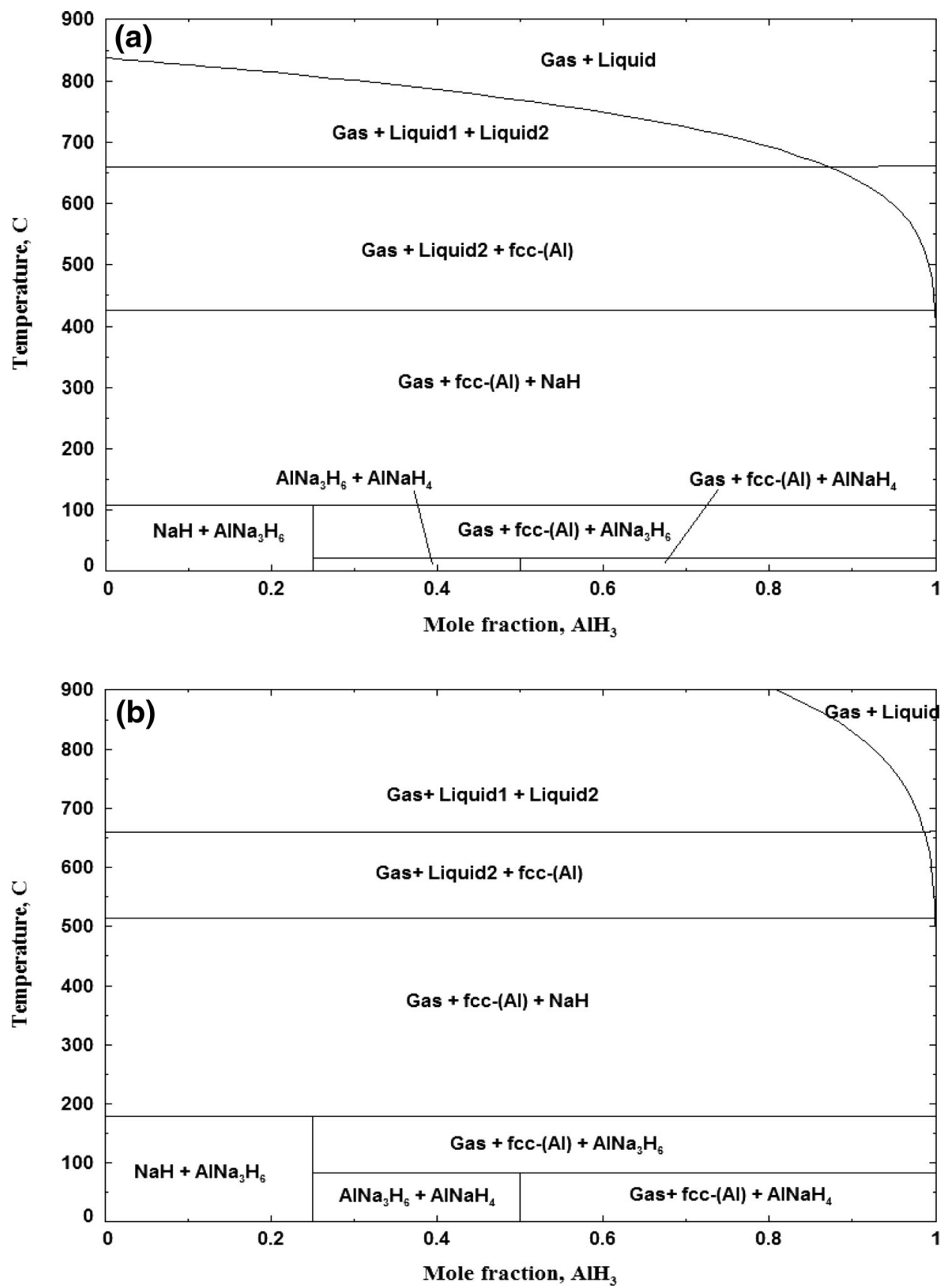

temperatures were 252, 248, and $243{ }^{\circ} \mathrm{C}$ for $\mathrm{MgH}_{2} / \mathrm{AlH}_{3}$ composites with molar ratios 1:0.25, 1:0.5, and 1:1, respectively. The reported onset temperature for the first decomposition of $\mathrm{MgH}_{2}$ [11] approaches gradually the calculated value of $234{ }^{\circ} \mathrm{C}$. This indicates that $\mathrm{AlH}_{3}$, in addition to destabilizing $\mathrm{MgH}_{2}$, improves its decomposition kinetics.

Second, Liu et al. [10] reported three stages during the thermal decomposition of the mixture $\mathrm{MgH}_{2}+\mathrm{AlH}_{3}$ using DSC-MS $\left(\mathrm{H}_{2}\right)$. The first stage was related to the decomposition of $\mathrm{AlH}_{3}$. The second stage, which might be composed of two overlapping peaks [10], was attributed to the reaction of $\mathrm{MgH}_{2}$ and $\mathrm{Al}$ to form the $\gamma$ phase. The last step was attributed to the melting of the $\gamma$ phase. $\mathrm{AlH}_{3}$, as shown in Fig. 2b, is not stable in normal conditions and will decompose spontaneously. The first stage observed by Liu et al. [10] can be explained by poor kinetics.

In Fig. 12a, the thermal decomposition steps of $\mathrm{MgH}_{2}+\mathrm{AlH}_{3}$ composite can be followed along the dotted red line, marking this composition. The process is as follows: 
Fig. 12 a The calculated $\mathrm{MgH}_{2}-\mathrm{AlH}_{3}$ phase diagram at 1 bar; $\mathbf{b}$ an enlarged view of $\mathbf{a}$
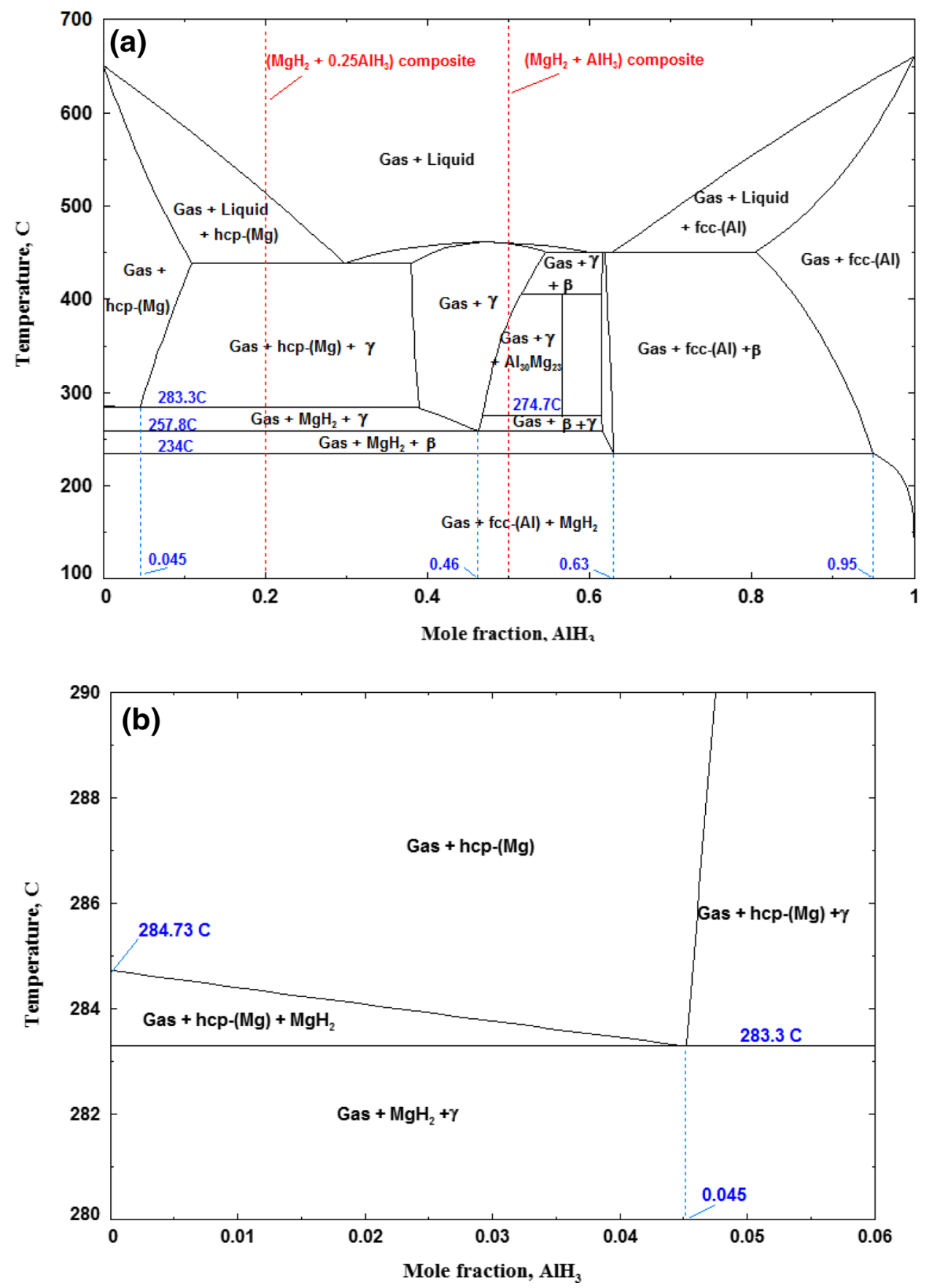

$$
\begin{aligned}
\mathrm{MgH}_{2}+\mathrm{fcc}-\mathrm{Al} & \stackrel{234^{\circ} \mathrm{C}}{\longrightarrow} \mathrm{MgH}_{2}+\beta+\mathrm{H}_{2} \stackrel{257.86^{\circ} \mathrm{C}}{\longrightarrow} \beta+\gamma+\mathrm{H}_{2} \stackrel{274.76^{\circ} \mathrm{C}}{\longrightarrow} \mathrm{Al}_{30} \mathrm{Mg}_{23}+\gamma+\mathrm{H}_{2} \\
& \stackrel{379.4^{\circ} \mathrm{C}}{\longrightarrow} \gamma+\mathrm{H}_{2} \stackrel{458.98<\mathrm{T}^{\circ} \mathrm{C}<460.16}{\longrightarrow} \text { Liquid }+\mathrm{H}_{2}
\end{aligned}
$$

Equation (8) shows an overall agreement with the results of Liu et al. [10] and gives a more detailed description of the process. This can be explained by the fact that the process suffers from poor kinetics and that the reaction temperatures are too close to observe distinct steps using DSC-MS $\left(\mathrm{H}_{2}\right)$ experiments. However, XRD analysis 
Fig. 13 Reaction path of $\mathrm{MgH}_{2}+0.25 \mathrm{AlH}_{3}$ showing the phase assemblage with temperature

Fig. 14 Calculated PCI curve of $\mathrm{Mg}-10$ at $\% \mathrm{Al}$ at $350{ }^{\circ} \mathrm{C}$
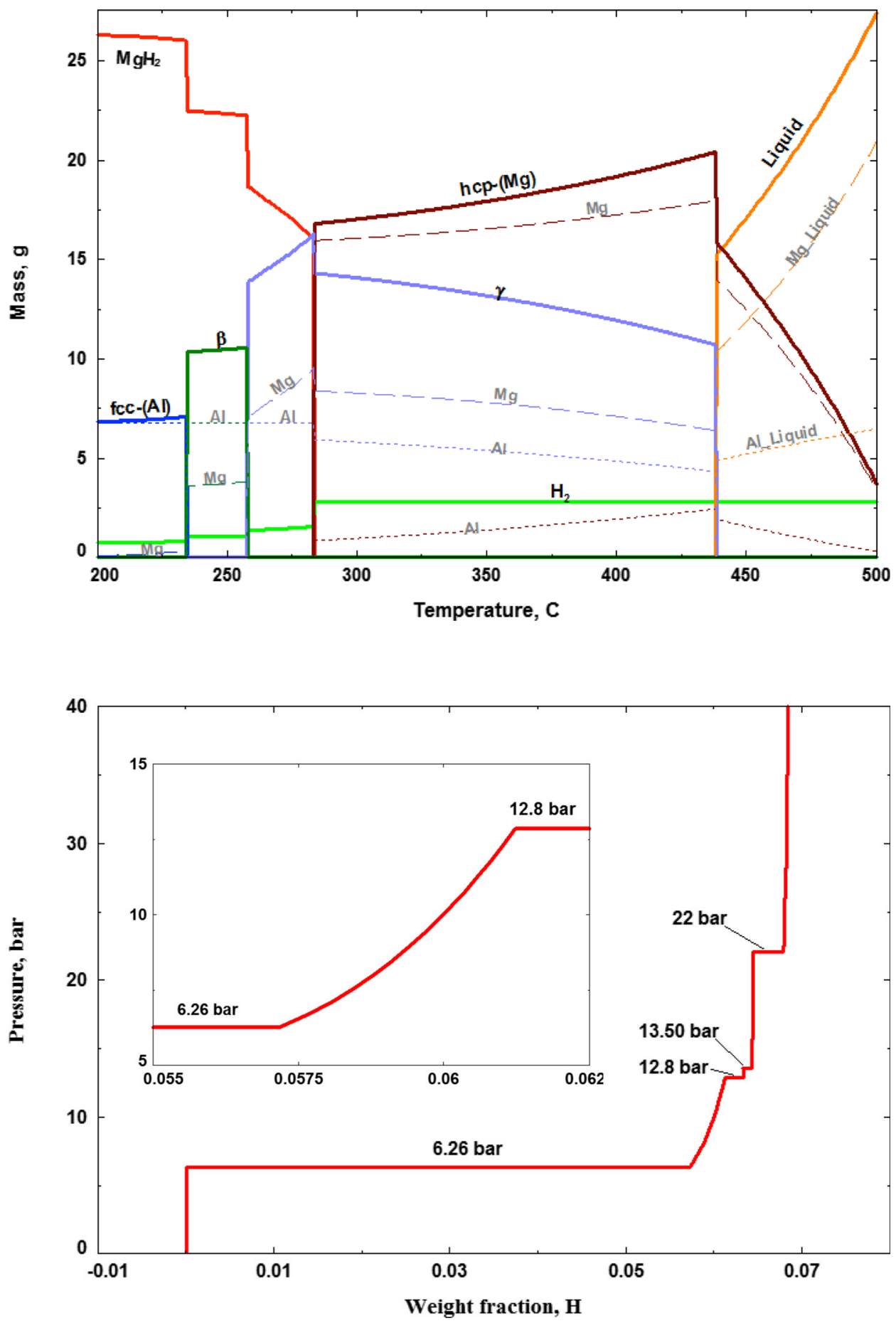

[10] showed that the mixture was composed of $\mathrm{MgH}_{2}$ and $\mathrm{Al}$ at $200{ }^{\circ} \mathrm{C}$, and of $\gamma$ phase at $400{ }^{\circ} \mathrm{C}$, which is consistent with the calculations shown in Eq. (8) and Fig. 12a.

Liu et al. [11] investigated the structure evolution during desorption of $\mathrm{MgH}_{2}+0.25 \mathrm{AlH}_{3}$ composites using $\mathrm{XRD}$ analysis of samples heated to various temperatures (from 175 to $400{ }^{\circ} \mathrm{C}$ ) with the same heating rate as in DSC-MS $\left(\mathrm{H}_{2}\right)$ experiments. They [11] reported a shift in the diffraction peaks of $\mathrm{Al}$ to small angles and the formation of $\beta$ phase when the temperature was increased from 250 to $310{ }^{\circ} \mathrm{C}$. They [11] attributed the $\mathrm{Al}$ peak shift to $\mathrm{Mg}$ atom dissolution in $\mathrm{Al}$ lattice causing its expansion until saturation where the new phase, $\beta\left(\mathrm{Al}_{3}\right.$ $\mathrm{Mg}_{2}$ ), formed. However, Liu et al. [11] neglected the fact that this peak shift might also be caused by thermal expansion of the Al lattice. 
In the following step, $\mathrm{MgH}_{2}$ reacts with $\beta$ to form the $\gamma$ phase [11]. In the final step, the residual $\mathrm{MgH}_{2}$ decomposes and only $\mathrm{Mg}$ solid solution and $\gamma$ phase were detected [11].

In Fig. 12a, the thermal decomposition steps of $\mathrm{MgH}_{2}+0.25 \mathrm{AlH}_{3}$ composite can be followed along the dotted red line marking this composition. It shows a very good agreement with the results of Liu et al. [11] concerning the structure evolution of the composite. From Fig. 12a, the decomposition process of $\mathrm{MgH}_{2}$ in the composite is as follows: formation of $\gamma$. For temperatures between 257.86 and $283.23{ }^{\circ} \mathrm{C}$, the amount of $\mathrm{MgH}_{2}$ decreases with temperature, while the amount of $\gamma$ increases simultaneously with the increase of the amount of $\mathrm{Mg}$ dissolved in it (purple dashed line). It should be noted that the amount of $\mathrm{Al}$ dissolved in the $\beta$ and $\gamma$ phases (dotted green and purple lines) is constant. At $283.23{ }^{\circ} \mathrm{C}$, the residual $\mathrm{MgH}_{2}$ decomposes resulting in the hcp-Mg phase.

The calculated PCI curve at $350{ }^{\circ} \mathrm{C}$ for $\mathrm{Mg}-10$ at $\% \mathrm{Al}$ alloy is presented in Fig. 14 and shows the presence of four

$\mathrm{MgH}_{2}+\mathrm{fcc}-\mathrm{Al} \stackrel{234^{\circ} \mathrm{C}}{\longrightarrow} \mathrm{MgH}_{2}+\beta+\mathrm{H}_{2} \stackrel{257.86^{\circ} \mathrm{C}}{\longrightarrow} \mathrm{MgH}_{2}+\gamma+\mathrm{H}_{2} \stackrel{283.23^{\circ} \mathrm{C}}{\longrightarrow}$ hcp- $(\mathrm{Mg})+\gamma+\mathrm{H}_{2}$

Equilibrium calculations of the reaction path provide more information about the amount of phases and their composition during the thermal decomposition of the composite. In Fig. 13, the calculated reaction path of $\mathrm{MgH}_{2}+0.25 \mathrm{AlH}_{3}$ composite at 1 bar is shown. The amount of phases is expressed in grams and is presented in solid lines with different colors for each phase. The amount of $\mathrm{Al}$ and $\mathrm{Mg}$ in each phase is presented with the same color as the phase, with dotted and dashed lines for $\mathrm{Al}$ and $\mathrm{Mg}$, respectively. It can be seen that, for temperatures above $200{ }^{\circ} \mathrm{C}$, the amount of fcc-Al (blue solid line) increases smoothly wth temperature, while the amount of $\mathrm{MgH}_{2}$ (red solid line) decreases. Simultaneously, the Al content of fcc-Al (blue dotted line) is constant and the $\mathrm{Mg}$ content of fcc-Al (blue dashed line) increases smoothly, which proves that $\mathrm{Al}$ destabilizes $\mathrm{MgH}_{2}$ at these temperatures and the resulting $\mathrm{Mg}$ atoms dissolve in fcc-Al and increase its amount until the temperature of $234{ }^{\circ} \mathrm{C}$, where the solubility limit of $\mathrm{Mg}$ in fcc- $\mathrm{Al}$ is reached and $\beta$ forms. This conclusion agrees very well with the XRD results reported in the literature [11, 38, 39, 41], observing the $\mathrm{Al}$ peak shift in the $\mathrm{MgH}_{2} / \mathrm{Al}$ composites with increasing temperature until it disappears and the $\beta$ formation occurs.

In Fig. 13 , at $234{ }^{\circ} \mathrm{C}$, it is seen that the formation of $\beta$ (presented with a dark green solid line) is accompanied by an abrupt decrease in the amount of $\mathrm{MgH}_{2}$ (the solid red line). A close look at $\mathrm{Al}$ and $\mathrm{Mg}$ content in $\beta$ shows that the amount of $\mathrm{Mg}$ in $\beta$ (dashed green line) increases abruptly at $234{ }^{\circ} \mathrm{C}$. This can be explained by the more important solubility of $\mathrm{Mg}$ in $\beta$. Since the first effective decomposition step of $\mathrm{MgH}_{2}$ in $\mathrm{MgH}_{2}-\mathrm{Al}$ mixtures is at $234{ }^{\circ} \mathrm{C}$, It can be concluded that the first effective destabilization step of $\mathrm{MgH}_{2}$ by $\mathrm{Al}$ is due to the formation of $\beta$. The same conclusions can be formed regarding the second step decomposition of $\mathrm{MgH}_{2}$ at $257.86{ }^{\circ} \mathrm{C}$ accompanied by the plateau regions at $6.26,12.8,13.5$, and 22 bar. The calculated hydriding reaction path of $\mathrm{Mg}-10$ at \% $\mathrm{Al}$ alloy at $350{ }^{\circ} \mathrm{C}$ is presented in Fig. 15. According to Figs. 13 and 14 , the initial composite is composed of hcp-Mg and $\gamma$ phases. The first plateau corresponds to the formation of $\mathrm{MgH}_{2}$ and an additional $\gamma$ phase from hcp-Mg. The second plateau corresponds to the hydriding of the $\gamma$ phase to produce $\mathrm{MgH}_{2}$ and $\mathrm{Al}_{30} \mathrm{Mg}_{23}$. The third plateau is attributed to the hydriding of $\mathrm{Al}_{30} \mathrm{Mg}_{23}$ to produce $\mathrm{MgH}_{2}$ and $\beta$. The forth plateau corresponds to the hydriding of the $\beta$ phase to produce $\mathrm{MgH}_{2}$ and fcc-Al.

The results shown in Figs. 14 and 15 are compared to the experimental data reported by Tanniru et al. [6]. These authors [6] reported the PCI curve at $350{ }^{\circ} \mathrm{C}$ and the microstructural evolution of the samples $(\mathrm{Mg}-10$ at\% $\mathrm{Al})$ during the measurements. However, they [6] could not identify the plateau pressures directly from the PCI curve because of the sloped and not well-defined plateaus resulting from the poor kinetics in addition to the small amount of hydrogen absorbed (below the theoretical capacity of the sample). For these reasons, a direct comparison between the calculated and the measured PCIs [6] is not possible. Nevertheless, the calculated plateau pressures are compared to those identified by Tanniru et al. [6]. Three hydriding steps corresponding to three plateaus at $6.2,12.7$, and 22 bar have been reported [6]. These results [6] are in very good agreement with the current calculations shown in Fig. 14 except for the calculated plateau pressure at 13.5 bar, which was not observed by these authors. This can be attributed to the small difference of pressure with the preceding step (12.8 bar) and the small length of the plateau in addition to the poor quality of the curve. Also, microstructural analysis and phase identification at different stages of hydriding/dehydriding 
experiments reported by Tanniru et al. [6] are in good agreement with this work. However, these authors [6] did not report the formation step of $\mathrm{Al}_{30} \mathrm{Mg}_{23}$ and therefore they combined the two-step hydriding reaction: $(\gamma$ to $\mathrm{Al}_{30} \mathrm{Mg}_{23}+\mathrm{MgH}_{2}$ at 12.8 bar and $\mathrm{Al}_{30} \mathrm{Mg}_{23}$ to $\beta+\mathrm{MgH}_{2}$ at 13.5 bar) in only one step: $\left(\gamma\right.$ to $\beta+\mathrm{MgH}_{2}$ at 12.7 bar). In Fig. 15, the amounts of $\mathrm{Al}$ and $\mathrm{Mg}$ in each phase are presented by dotted and dashed lines, respectively, with the same color as the phase. It can be seen in Fig. 15 that from a pressure of 6.26 and 12.8 bar, the alloy is composed of $\gamma$ phase and $\mathrm{MgH}_{2}$ and the amount of $\mathrm{MgH}_{2}$ increases gradually in this pressure range, while the amount
Fig. 15 Hydriding reaction path of $\mathrm{Mg}-10$ at $\% \mathrm{Al}$ at $350{ }^{\circ} \mathrm{C}$

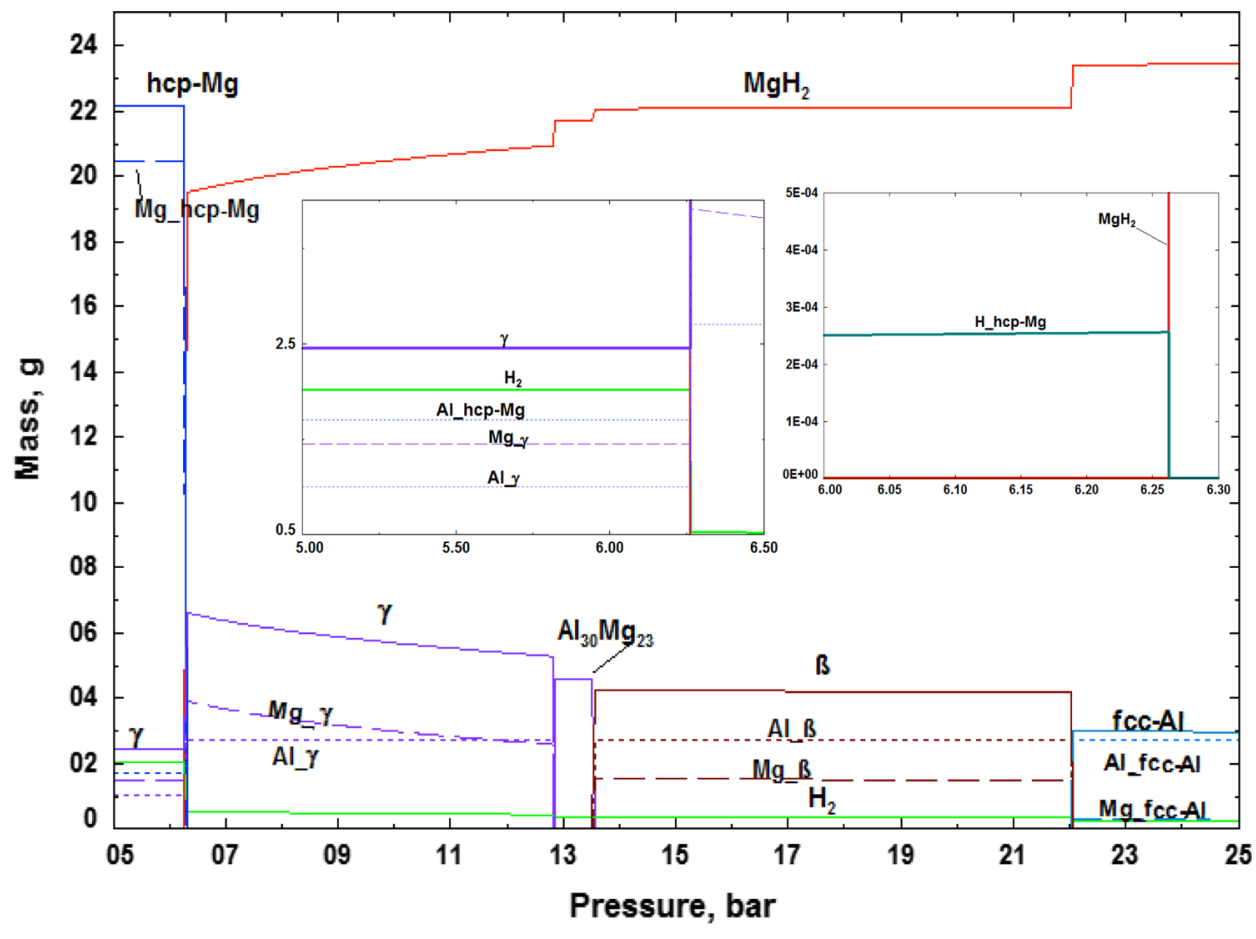

Fig. 16 The calculated $\mathrm{MgH}_{2}-$ $\mathrm{Al}$ phase diagram at $350{ }^{\circ} \mathrm{C}$

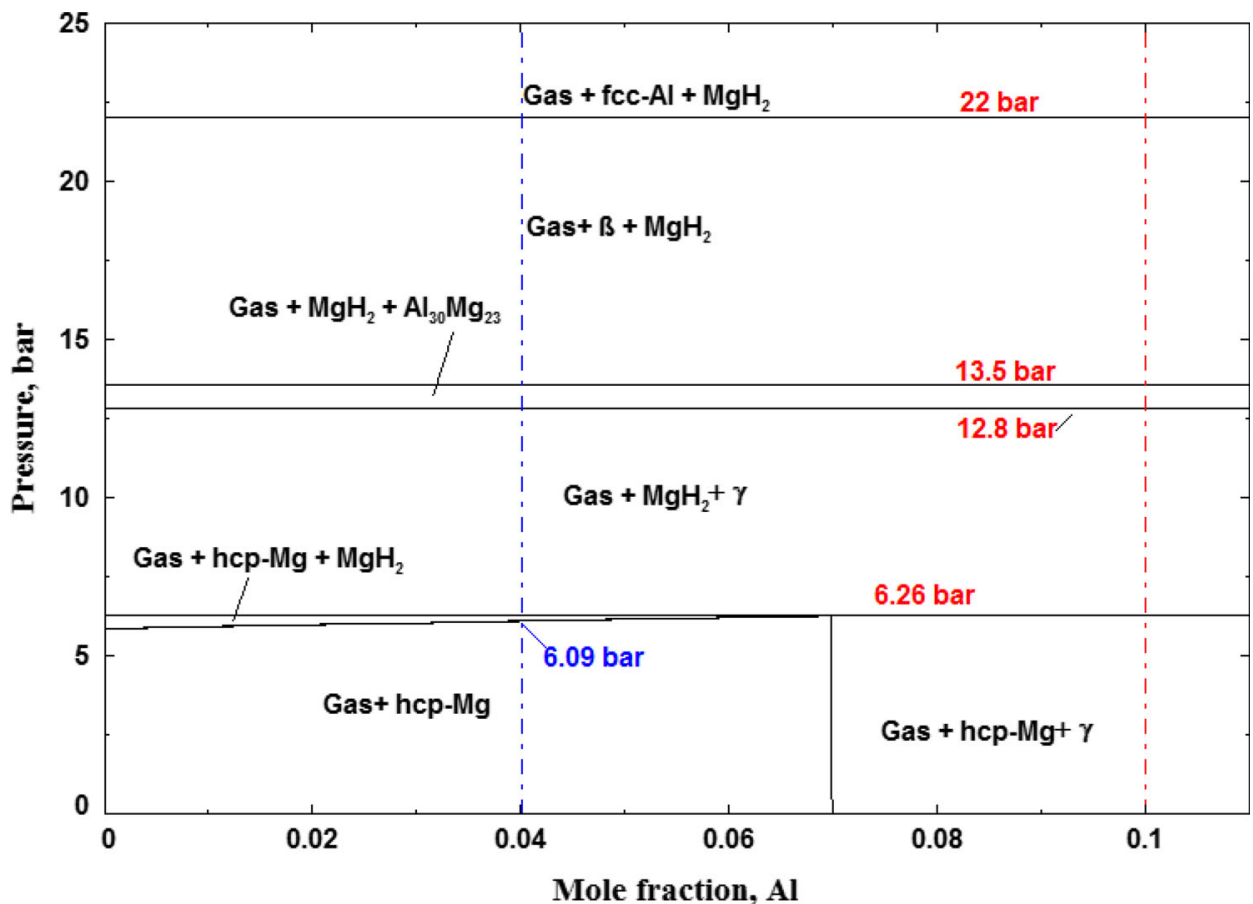

Mole fraction, Al 
of $\mathrm{Mg}$ in the $\gamma$ phase decreases and the amount of $\mathrm{Al}$ in the $\gamma$ phase is constant, which signifies that the $\gamma$ phase is more concentrated in Al. This step takes the form of a curved line in PCI curves (the enlarged inset in Fig. 14) and is due to the large solubility range of the $\gamma$ phase. Bouaricha et al. [54] reported that the PCI curves of $\mathrm{Mg}-\mathrm{Al}$ alloys with $\gamma$ phase compositions showed sloped plateau between 8 and 15 bar, which is consistent with the trend of the PCIs calculated in this work. It can be concluded that the PCI inclined plateaus reported in the literature [46] for the Al$\mathrm{Mg}$ alloys, is, in addition to kinetic factors, due to the large solubility range of the $\gamma$ phase, short plateaus' length, and the small differences between the last three plateau pressures.

Tanniru et al. [6] reported that the first plateau pressures increased on increasing $\mathrm{Al}$ content $(5.4,5.7$, and 6.2 bar for $\mathrm{Mg}, \mathrm{Mg}-4$ at\% $\mathrm{Al}$, and $\mathrm{Mg}-10$ at\% $\mathrm{Al}$, respectively) and attributed this raise in pressure to kinetic factors. To investigate the variation of the first plateau pressure with $\mathrm{Al}$ content, the calculated phase diagram of $\mathrm{MgH}_{2}-\mathrm{Al}$ [ $\mathrm{Al}$ content between 0 and 11 at $\%(0.11 \mathrm{~mol}$ fraction)] alloy at $350{ }^{\circ} \mathrm{C}$ is presented in Fig. 16.

It shows that for $\mathrm{Al}$ content above 7 at $\%$, the starting alloy is composed of hcp-Mg and $\gamma$ phase and the hydriding of these alloys follows the same processes as for the Mg-10 at\% Al alloys presented in Figs. 13 and 14. Mg10 at $\% \mathrm{Al}$ composition is marked with dashed red line in Fig. 16, which shows the four-hydriding steps with increase in the pressure. For $\mathrm{Al}$ content below 7 at $\%$, the starting alloy is composed of hcp- $\mathrm{Mg}$, and an additional step in the hydriding of alloys with these compositions is shown. This step occurs at a pressure which depends on the $\mathrm{Al}$ content and ranges between 5.84 bar for pure $\mathrm{Mg}$ to 6.26 bar for $\mathrm{Al}$ content of 7 at $\%$. As example, $\mathrm{Mg}-4$ at $\% \mathrm{Al}$ composition is marked with dashed blue line in Fig. 16 and shows that the first hydriding step for alloys with this composition occurs at 6.09 bar. The calculated PCI curve at $350{ }^{\circ} \mathrm{C}$ for $\mathrm{Mg}-4$ at\% $\mathrm{Al}$ alloy is presented in Fig. 17. The enlarged portion of the first plateau shows that what can be seen as one plateau pressure is in fact composed of a curved portion starting at 6.09 bar followed by a straight one at 6.26 bar. Of course, this difference could not be observed in the experimental PCI [6], but it explains the variations in the first plateau pressure with $\mathrm{Al}$ content reported by Tanniru et al. [6].

Figure 18 shows the calculated hydriding reaction pathway of $\mathrm{Mg}-4$ at $\% \mathrm{Al}$ alloy at $350{ }^{\circ} \mathrm{C}$ for pressures near the first plateau pressure. It shows that $\mathrm{MgH}_{2}$ starts forming at a pressure of 6.09 bar and its amount (red line) increases gradually with decreasing amount of hcp-Mg (blue line) as the pressure increases. The amount of $\mathrm{Al}$ dissolved in hcp$\mathrm{Mg}$ (blue dotted line) is constant, while the amount of $\mathrm{Mg}$ in hcp-Mg (blue dashed line) decreases, which means that the hcp-Mg phase is more concentrated in $\mathrm{Al}$ while $\mathrm{MgH} 2$ is forming. The enlarged view shows that the amount of $\mathrm{H}$ in hcp-Mg decreases with the pressure too. At 6.26 bar, hcp-Mg is hydrided and the $\gamma$ phase forms. It can be concluded from the calculations shown in Figs. 15, 16, and 17
Fig. 17 Calculated PCI curve of $\mathrm{Mg}-4$ at\% $\mathrm{Al}$ at $350{ }^{\circ} \mathrm{C}$

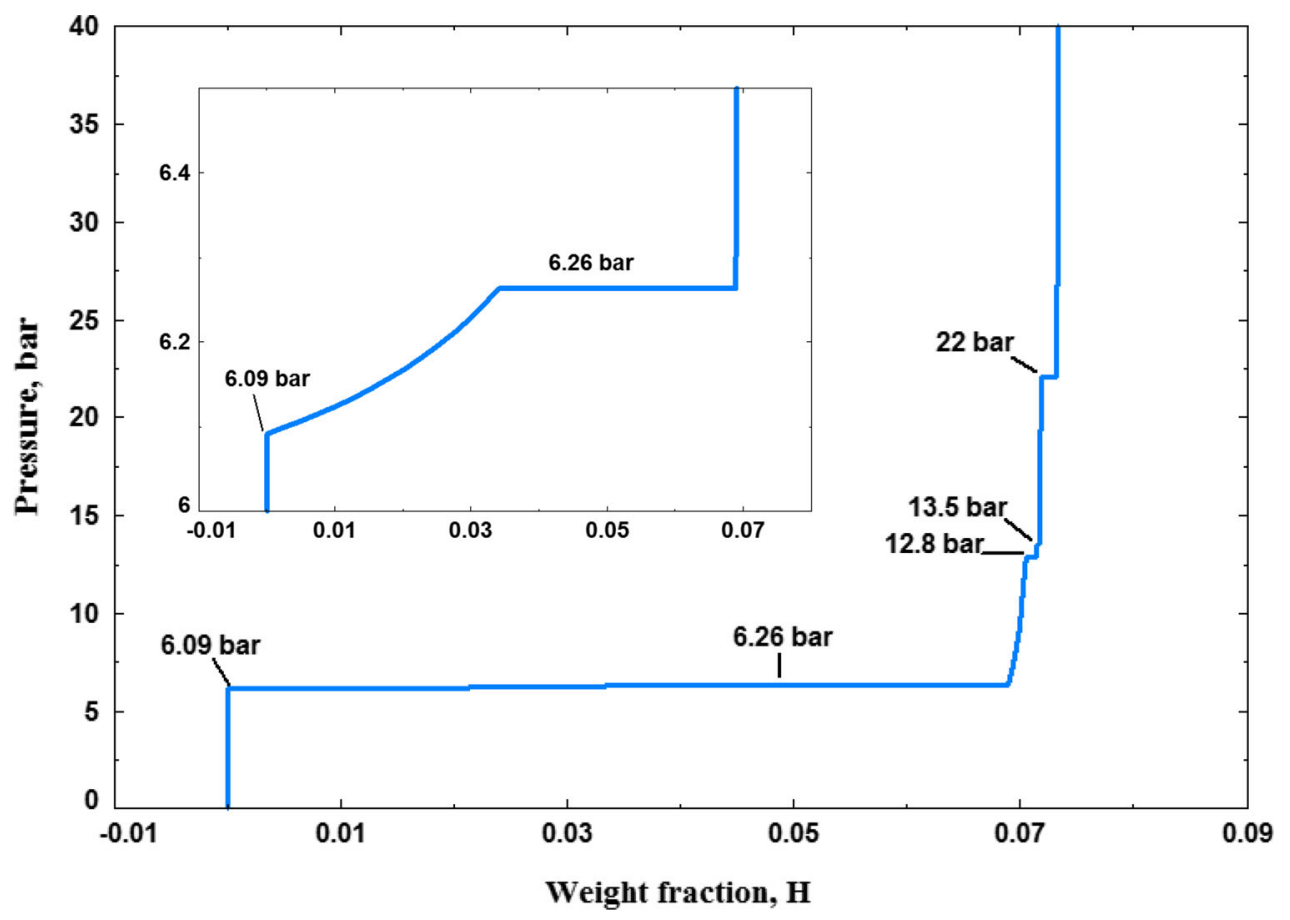


that the variations in the first plateau pressure reported in the literature is due to the solubility of $\mathrm{Al}$ in hcp-Mg and not to kinetic factors as suggested by Tanniru et al. [6].

The Al-Mg-Na-H system

As mentioned in "Al-Mg-Na-H system", Ismail et al. [79] investigated the hydrogen storage properties and the reaction pathways of $\mathrm{MgH}_{2}-\mathrm{NaAlH}_{4}$ (4:1)/ $\mathrm{Na}_{3} \mathrm{AlH}_{6}$ (4:1) composites. In this section, their results are compared with our thermodynamic calculations.

The calculated $\mathrm{MgH}_{2}-\mathrm{NaAlH}_{4}$ phase diagram is presented in Fig. 19 and shows the different reaction stages in the thermal decomposition of $\mathrm{MgH}_{2} / \mathrm{NaAlH}_{4}$ composites at 1 bar.

It can be seen that the reaction pathway in the $\mathrm{MgH}_{2} /$ $\mathrm{NaAlH}_{4}$ composites depends on the relative amounts of the
Fig. 18 Hydriding reaction path of Mg-4 at\% $\mathrm{Al}$ at $350{ }^{\circ} \mathrm{C}$

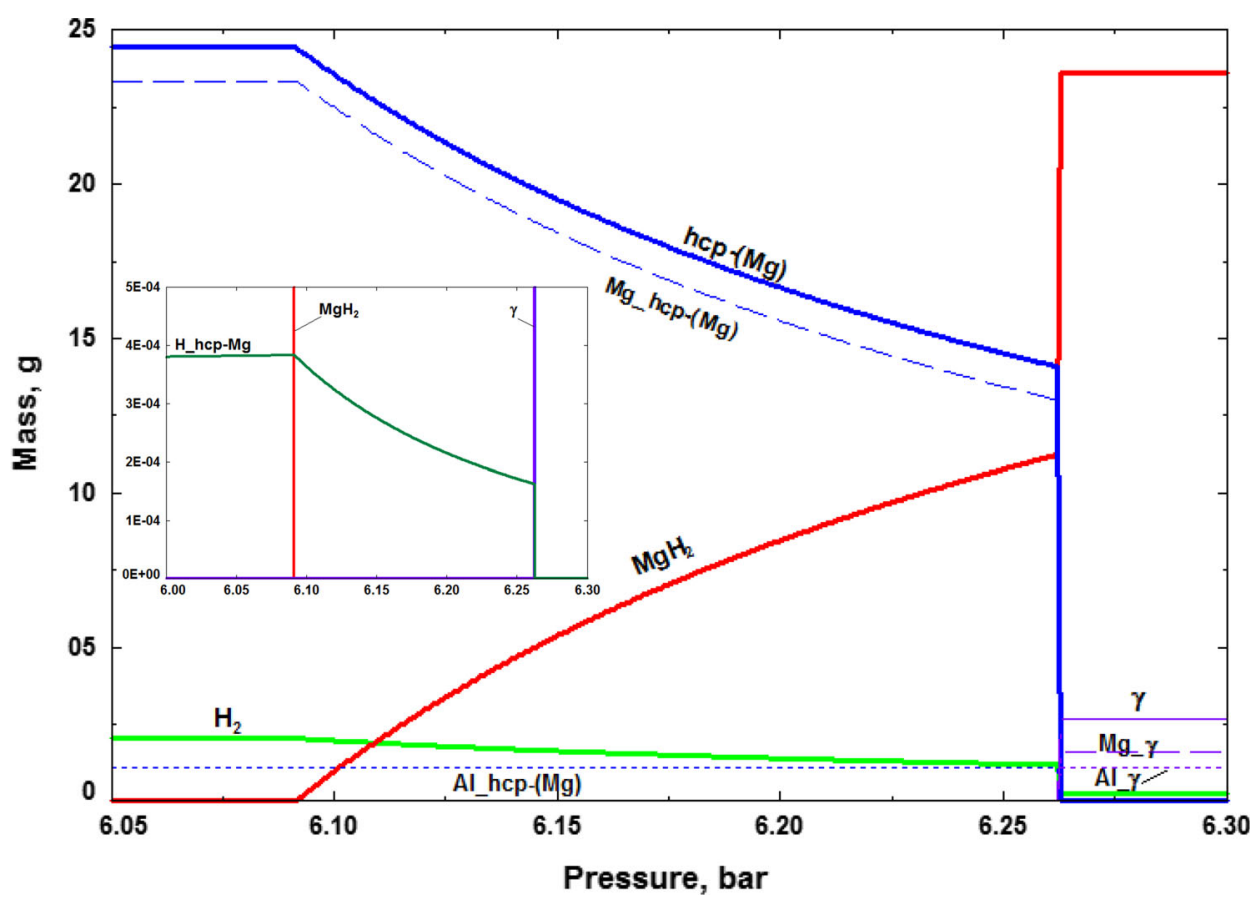

Fig. 19 The calculated $\mathrm{MgH}_{2}-$ $\mathrm{AlNaH}_{4}$ phase diagram at 1 bar

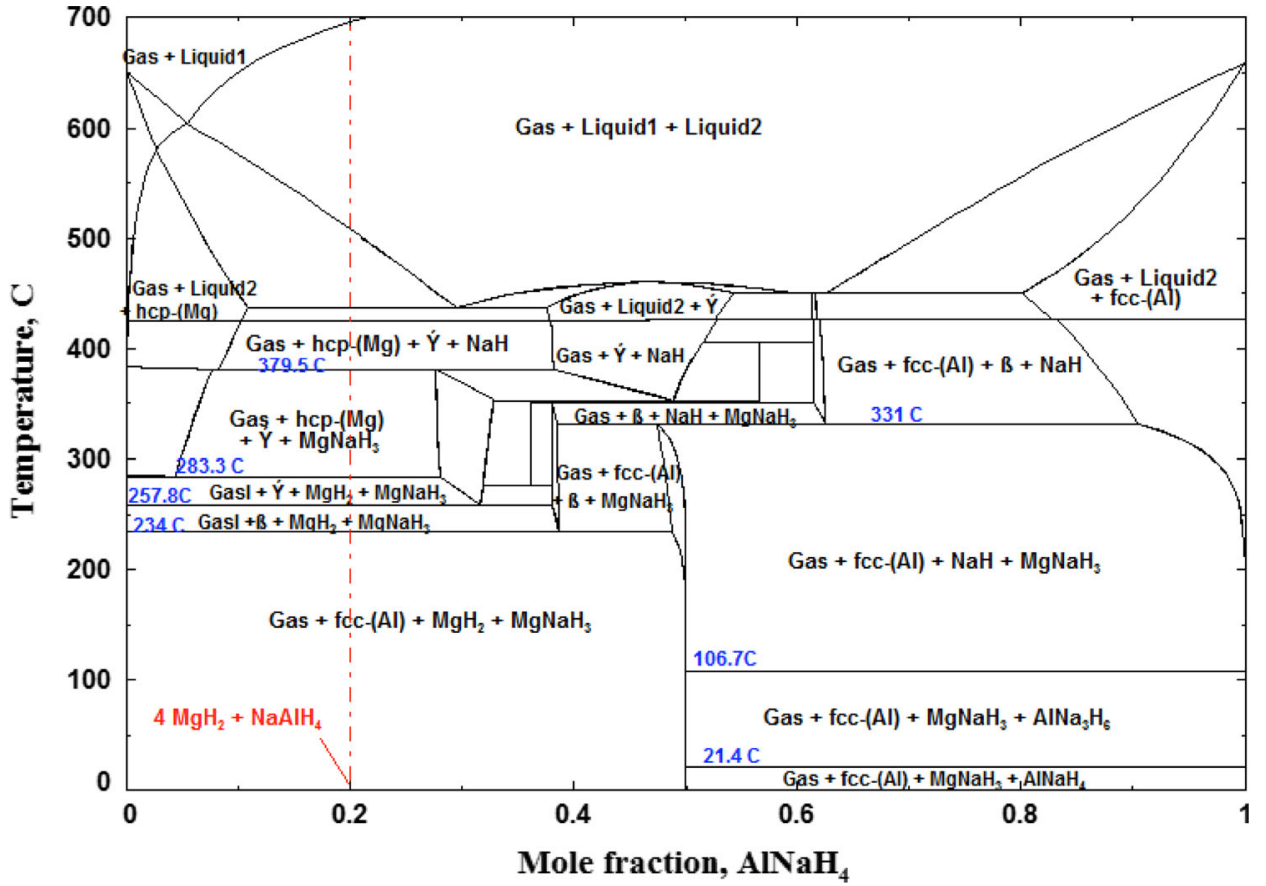

Mole fraction, $\mathrm{AlNaH}_{4}$ 
components. For $\mathrm{MgH}_{2}-\mathrm{NaAlH}_{4}$ (4:1) composition (marked by red dashed line in Fig. 19), NaAlH4 reacts spontaneously with $\mathrm{MgH}_{2}$ to form $\mathrm{NaMgH}_{3}, \mathrm{MgH}_{2}$, and fcc-Al. Then, as already discussed in "Al-Mg-H system", $\mathrm{MgH}_{2}$ interacts with fcc-Al and decomposes in three steps: at $234{ }^{\circ} \mathrm{C}$ (when $\beta$ is formed), at $257.86{ }^{\circ} \mathrm{C}$ (when $\gamma$ is formed), and at $283.29{ }^{\circ} \mathrm{C}$ (when $\gamma$ and hcp-Mg are formed). Finally, $\mathrm{NaMgH}_{3}$ and $\mathrm{NaH}$ decompose at 379.48 and $424.8^{\circ} \mathrm{C}$, respectively. The (TPD) results [8] showed that four stages of $4 \mathrm{MgH}_{2}-\mathrm{NaAlH}_{4}-\mathrm{TiF}_{3}$ desorption have been observed in the temperature ranges $\left(60-200{ }^{\circ} \mathrm{C}\right)$, $\left(200-315^{\circ} \mathrm{C}\right), \quad\left(315-370{ }^{\circ} \mathrm{C}\right), \quad$ and $\left(\right.$ after $\left.375^{\circ} \mathrm{C}\right)$, respectively.

The results of Ismail et al. [7, 8] are in agreement with the calculations performed in this work. However, the first stage desorption reported by Ismail et al. [7, 8] was attributed to the reaction between a part of $\mathrm{MgH}_{2}$ and $\mathrm{NaAlH}_{4}$ to form $\mathrm{NaMgH}_{3}$ and Al. This reaction happens spontaneously according to our calculation and might be kinetically hindered. Ismail et al. [7, 8] reported the decomposition of $\mathrm{MgH}_{2}$ as a one-step process and this might be due, in addition to kinetics factor, to the small differences in the three steps reaction temperatures (234, 257.8 , and $283.29^{\circ} \mathrm{C}$, respectively) calculated in this work. In addition to that, the desorption temperatures reported [8] are in a good agreement with the calculated ones at 1 bar considering the fact that the TPD experiments were performed in vacuum [7, 8].

It should be noted that according to the calculation reported in Fig. 19 (the red dashed line for
$4 \mathrm{MgH}_{2}+\mathrm{NaAlH}_{3}$ composition) and the results reported in "Al-Mg-H system" Fig. 12a (the red dashed line for $\mathrm{MgH}_{2}+0.25 \mathrm{AlH}_{3}$ composition), $\mathrm{NaMgH}_{3}$ does not affect the decomposition temperatures of $\mathrm{MgH}_{2}+\mathrm{Al}$ mixtures. However, the decomposition temperature of $\mathrm{NaMgH}_{3}$ is decreased from $382.63{ }^{\circ} \mathrm{C}$ for pure $\mathrm{NaMgH}_{3}$ [2] to $379.48{ }^{\circ} \mathrm{C}$ in the $\mathrm{MgH}_{2}-\mathrm{NaAlH}_{4}$ (4:1) composite.

Figure 19 shows the reaction processes in $\mathrm{MgH}_{2}-$ $\mathrm{NaAlH}_{4}$ composites for the whole composition range. According to our calculations, it is predicted that for $\mathrm{NaAlH}_{4}$ content above $0.5 \mathrm{~mol}$ fraction (in Fig. 19), $\mathrm{MgH}_{2}$ decomposes spontaneously and the system is initially composed of fcc-Al, $\mathrm{MgNaH}_{3}$, and $\mathrm{AlNaH}_{4}$. The first and the second reaction steps concern the decomposition of $\mathrm{AlNaH}_{4}$ and $\mathrm{AlNa}_{3} \mathrm{H}_{6}$ at the hydrides' decomposition temperatures, 21.4 and $106.7^{\circ} \mathrm{C}$, respectively, which shows that these hydrides are not altered by $\mathrm{Al}$ or $\mathrm{MgNaH}_{3}$. Between 0.62 and $0.9 \mathrm{~mol}$ fractions of $\mathrm{NaAlH}_{4}, \mathrm{NaMgH}_{3}$ decomposes in one step at $331{ }^{\circ} \mathrm{C}$. This temperature is $51.63{ }^{\circ} \mathrm{C}$ lower than the decomposition temperature of pure $\mathrm{NaMgH}_{3}$. This fact proves that $\mathrm{Al}$ alters the decomposition process of $\mathrm{NaMgH}_{3}$. The reaction pathway of $0.2 \mathrm{Al}+0.8 \mathrm{NaMgH}_{3}$ composite is presented in Fig. 20 . The $\mathrm{Al}$ and $\mathrm{Mg}$ content of each phase are presented in the enlarged inset with dotted and dashed lines, respectively, with the same color as the phase. It is shown that $\mathrm{MgNaH}_{3}$ decomposes in four steps with the formation of $\beta, \mathrm{Al}_{30}$ $\mathrm{Mg}_{23}, \gamma$, and hcp-Mg at 331, 350.27, 352.19, and $379.48{ }^{\circ} \mathrm{C}$, respectively. In each step, $\mathrm{NaH}$ and $\mathrm{H}_{2}$ are also formed. It should be noted that with increasing
Fig. 20 Reaction path of the reaction $0.2 \mathrm{Al}+0.8 \mathrm{NaMgH}_{3}$ at $1 \mathrm{bar}$

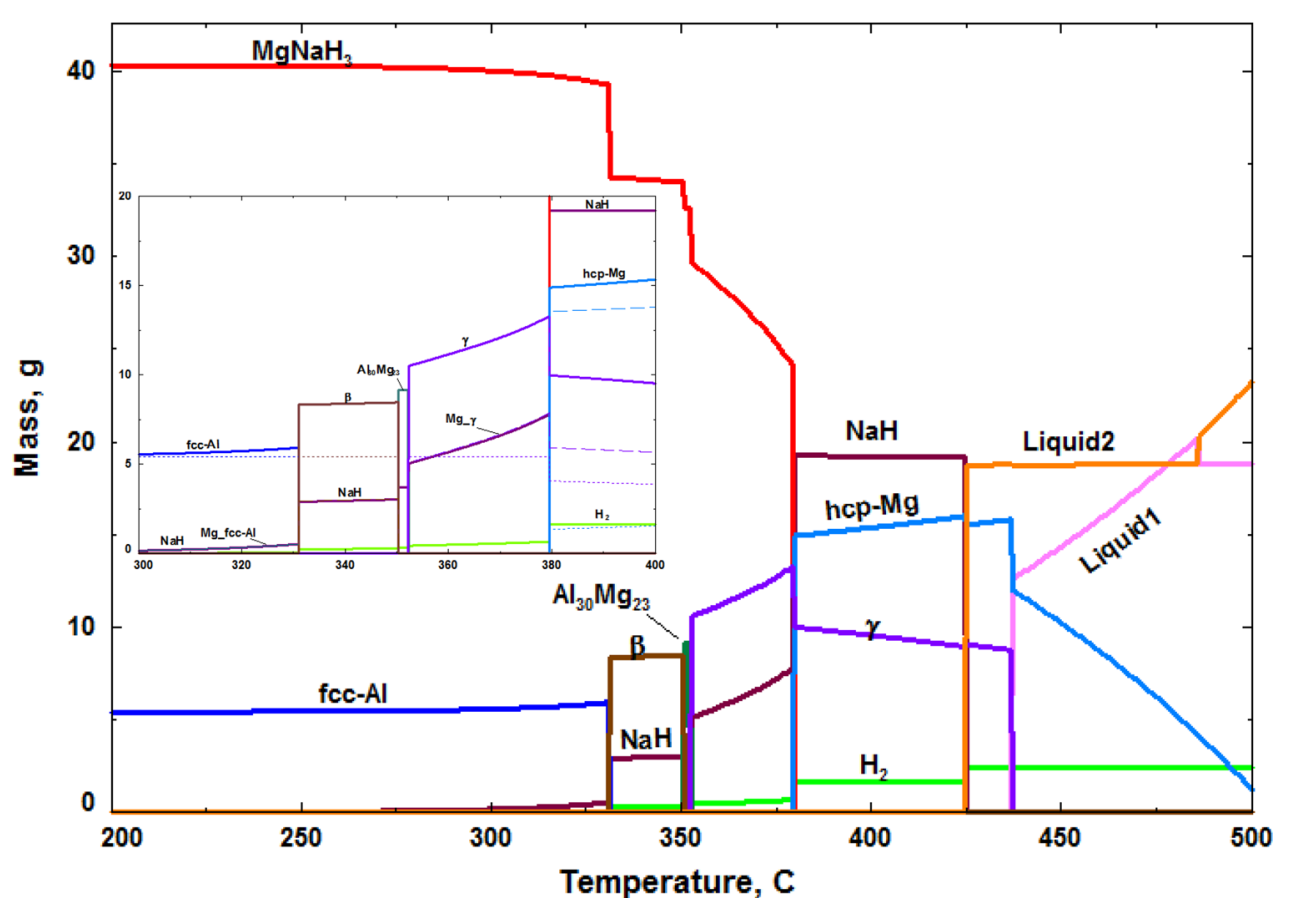


temperature, Fig. 20 shows that the amount of $\mathrm{MgNaH}_{3}$ starts decreasing at temperatures below $331{ }^{\circ} \mathrm{C}$ and that the amount of fcc-Al increases while its $\mathrm{Al}$ content is constant. The amount of $\mathrm{NaH}$ in the composite increases too. We can conclude that, when $\mathrm{Al}$ is added to $\mathrm{MgNaH}_{3}$, some $\mathrm{Mg}$ starts dissolving in fcc- $\mathrm{Al}$ forming $\mathrm{NaH}$ and liberating some $\mathrm{H}_{2}$ until fcc-Al saturation where $\beta$ forms at $331{ }^{\circ} \mathrm{C}$. The same conclusion can be drawn regarding $\mathrm{Mg}$ solubility in $\beta$ and $\gamma$.

Ismail et al. [7] demonstrated that the reactions in $\mathrm{MgH}_{2}-\mathrm{NaAlH}_{4}$ (4:1) composite are reversible at 30 bar $\mathrm{H}_{2}$ pressure and $300{ }^{\circ} \mathrm{C}$, except the first one (reaction between $\mathrm{MgH}_{2}$ and $\mathrm{NaAlH}_{4}$ to form $\mathrm{NaMgH}_{3}$ and $\mathrm{Al}$ ), and that the phases present in the composite after rehydrogenation are $\mathrm{MgH}_{2}, \mathrm{NaMgH}_{3}$, and Al. The calculated PT diagram of $\mathrm{MgH}_{2}-\mathrm{NaAlH}_{4}$ (4:1) composites is shown in Fig. 21. It shows also that at $300{ }^{\circ} \mathrm{C}$ and 30 bar (marked in the Fig. 21 by blue point), the composite is composed of $\mathrm{MgH}_{2}, \mathrm{NaMgH}_{3}$, and fcc-Al phases, which agree with the results of Ismail et al. [7, 8]. In addition to these phases, Ismail et al. [7, 8] reported that XRD measurements showed a small peak of $\beta$ phase in addition to $\mathrm{Al}_{3} \mathrm{Ti}$ phase when $\mathrm{TiF}_{3}$ was added to the mixture. $\mathrm{Al}_{3} \mathrm{Ti}$ and $\mathrm{TiF}_{3}$ act as catalysts to improve the desorption kinetics of the mixture $[7,8]$.

Ismail et al. [7, 8] showed that the absorption kinetics after the first desorption of the composite was slow compared to $\mathrm{MgH}_{2}$ and that addition of $\mathrm{TiF}_{3}$ did not improve it. This slow absorption kinetics has been related to the presence of $\beta$ whose hydrogenation is kinetically hindered $[7,8]$.
It can be concluded from these calculations and the work of Ismail et al. [7, 8] that $\mathrm{NaAlH}_{4}$ is destabilized by $\mathrm{MgH}_{2}$ and decomposes spontaneously in the mixture $\mathrm{MgH}_{2}-$ $\mathrm{NaAlH}_{4}$ (4:1). Then, the produced $\mathrm{Al}$ destabilizes $\mathrm{MgH}_{2}$. But the re-hydrogenation reactions kinetics is very slow.

Ismail et al. [9] investigated the hydrogen storage properties of the $\mathrm{MgH}_{2}-\mathrm{Na}_{3} \mathrm{AlH}_{6}$ (4:1) composite and concluded that the reaction mechanisms were similar to that of the $\mathrm{MgH}_{2}-\mathrm{NaAlH}_{4}$ (4:1) composite. The calculated $\mathrm{MgH}_{2}-\mathrm{Na}_{3} \mathrm{AlH}_{6}$ phase diagram is presented in Fig. 22 and is very similar to the calculated $\mathrm{MgH}_{2}-\mathrm{NaAlH}_{4}$ phase diagram. A red dashed line in Fig. 22 shows the $\mathrm{MgH}_{2}-$ $\mathrm{Na}_{3} \mathrm{AlH}_{6}$ (4:1) composition. It shows that $\mathrm{MgH}_{2}$ decomposes in two steps with the formation of $\beta$ phase in the first step and $\gamma$ with $\beta$ phases after the second step. The present calculations show the formation of $\mathrm{Al}_{30} \mathrm{Mg}_{23}$, which has not been reported in the literature. Figure 22 shows that a small variation in the mixture composition will result in identical reaction mechanisms as with $\mathrm{MgH}_{2}-\mathrm{NaAlH}_{4}$ (4:1) composite. It might be the case in the results published by Ismail et al. [9].

The calculated PT diagram of $\mathrm{MgH}_{2}-\mathrm{Na}_{3} \mathrm{AlH}_{6}$ (4:1) composites is shown in Fig. 23. It shows that $\mathrm{Na}_{3} \mathrm{AlH}_{6}$ is not stable in this mixture even under very high pressures. XRD results [9] showed that the rehydrogenated composite at 30 bar and $300{ }^{\circ} \mathrm{C}$, was composed of $\mathrm{MgH}_{2}, \mathrm{NaMgH}_{3}$, $\mathrm{Al}$, and a small amount of $\beta$ which agrees with the calculations performed in this work (Fig. 23), except for the existence of $\beta$ which shows that its hydrogenation process is very slow.
Fig. $21 \mathrm{P}-\mathrm{T}$ diagram of the $4 \mathrm{MgH}_{2}+\mathrm{NaAlH}_{4}$ composite

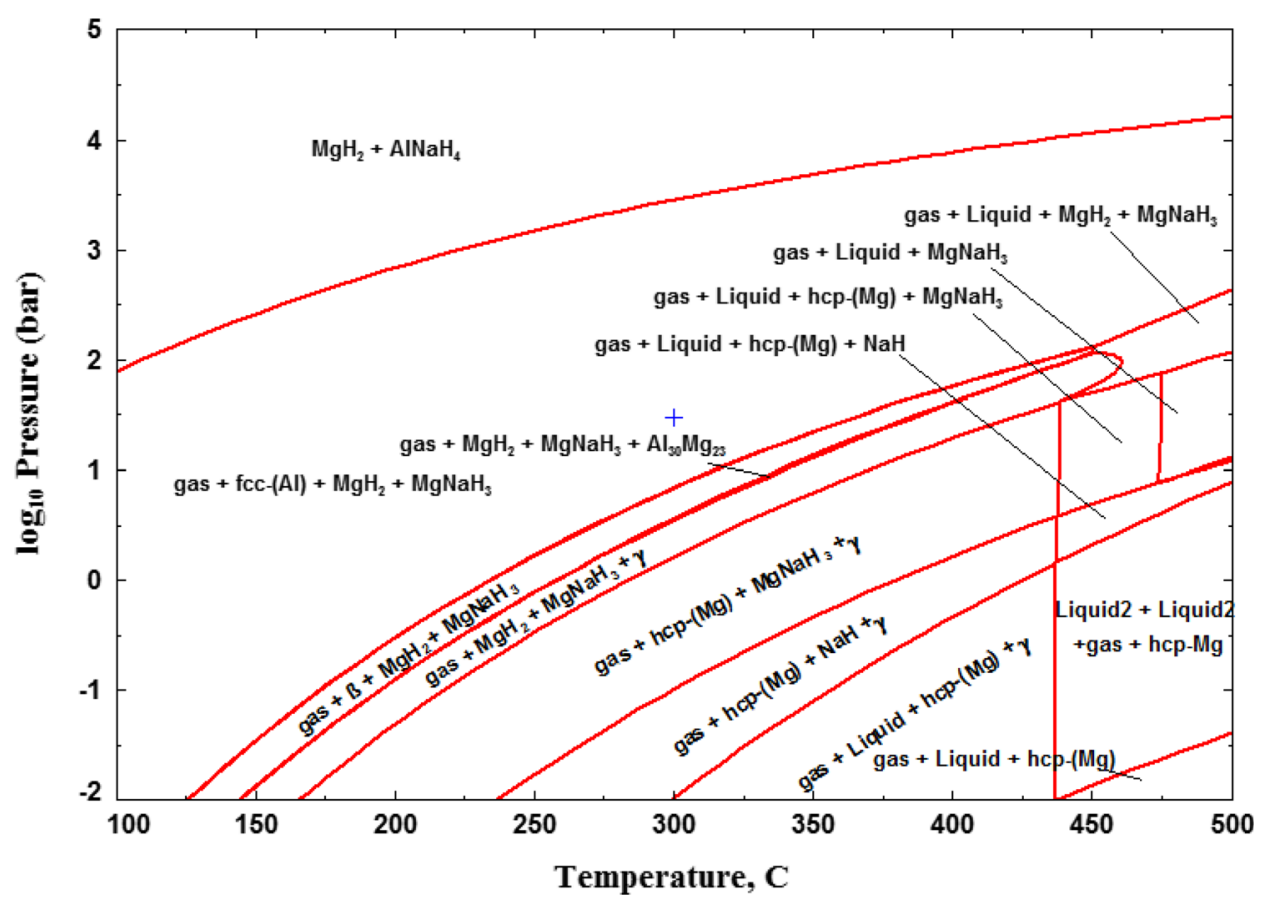

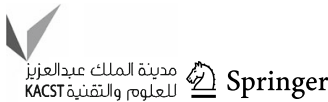


Fig. 22 The calculated $\mathrm{MgH}_{2}-$ $\mathrm{AlNa}_{3} \mathrm{H}_{6}$ phase diagram at $1 \mathrm{bar}$

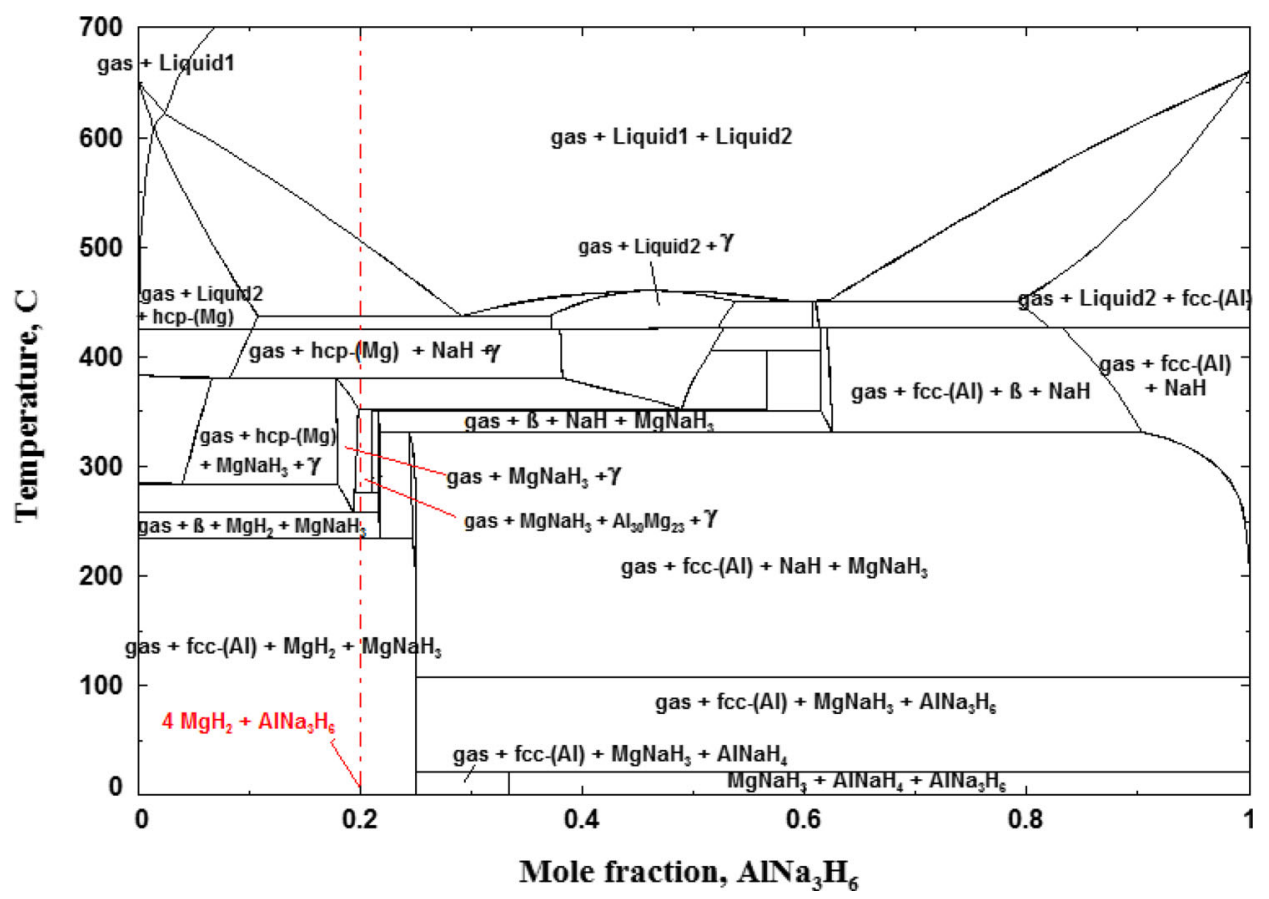

Fig. 23 P-T diagram of the $4 \mathrm{MgH}_{2}+\mathrm{Na}_{3} \mathrm{AlH}_{6}$ composite

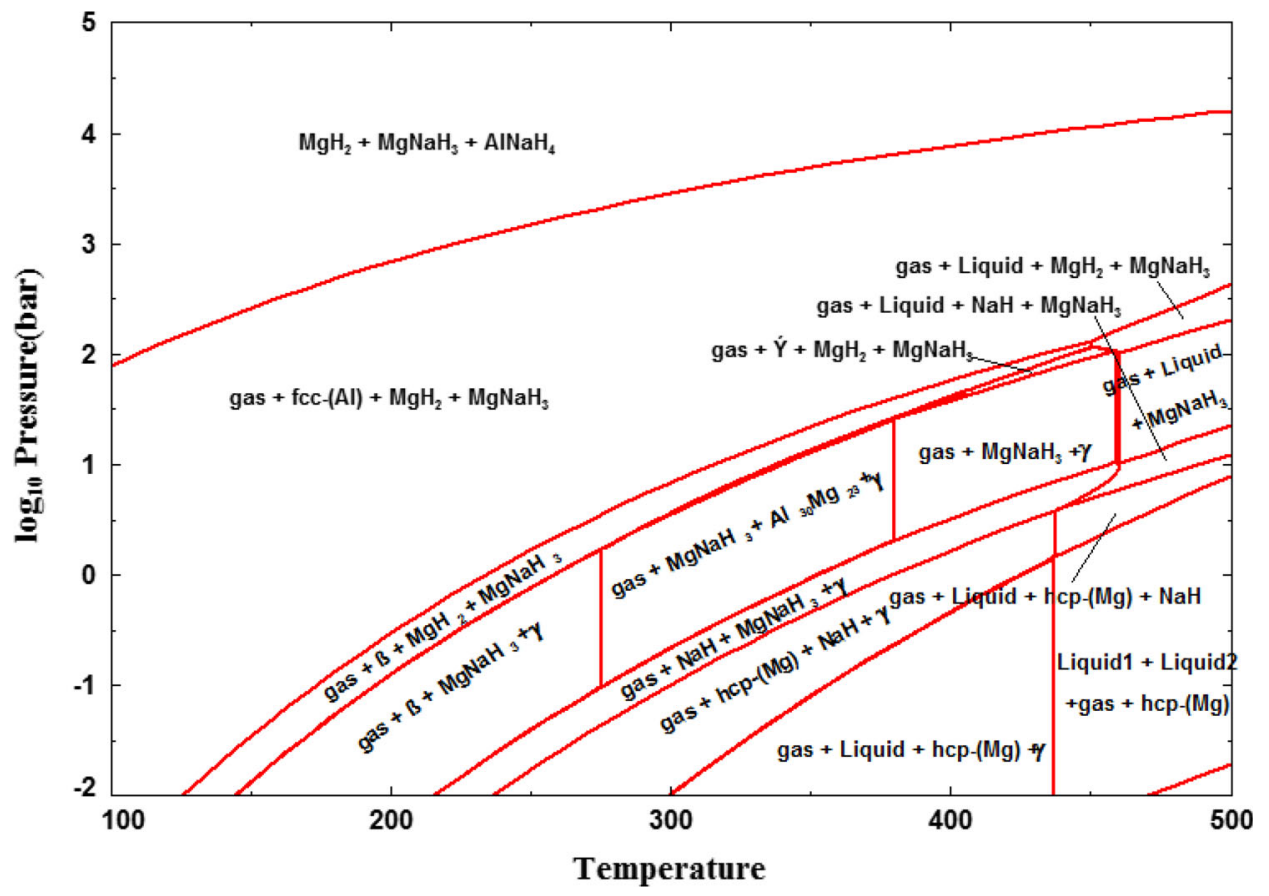

According to the thermodynamic calculations conducted in this work, at 1 bar, $\mathrm{AlNaH}_{4}$ decomposes to form $\mathrm{AlNa}_{3} \mathrm{H}_{6}$ and fcc-Al at $21.4{ }^{\circ} \mathrm{C}$, and $\mathrm{AlNa}_{3} \mathrm{H}_{6}$ decomposes to form $\mathrm{NaH}$ and fcc-Al at $106.7^{\circ} \mathrm{C}$. When mixed with $\mathrm{MgH}_{2}, \mathrm{MgNaH}_{3}$ forms spontaneously from $\mathrm{MgH}_{2}$ and $\mathrm{AlNaH}_{4} / \mathrm{AlNa}_{3} \mathrm{H}_{6}$ and the resulting mixture composition depends on the relative amounts of the components.
When the number of $\mathrm{Mg}$ atoms in $\mathrm{MgH}_{2}+\mathrm{AlNaH}_{4} /$ $\mathrm{AlNa}_{3} \mathrm{H}_{6}$ mixture exceeds the number of $\mathrm{Na}$ atoms, all the $\mathrm{AlNaH}_{4} / \mathrm{AlNa}_{3} \mathrm{H}_{6}$ decomposes spontaneously and the remaining decomposition steps concern the decomposition of $\left(\mathrm{MgH}_{2}+\mathrm{Al}\right)$ mixture and $\mathrm{MgNaH}_{3}$ has only a catalytic role.

When the number of $\mathrm{Na}$ atoms in the $\mathrm{MgH}_{2}+\mathrm{AlNaH}_{4} /$ $\mathrm{AlNa}_{3} \mathrm{H}_{6}$ mixture exceeds the number of $\mathrm{Mg}$ atoms, $\mathrm{MgH}_{2}$ 
decomposes spontaneously and the remaining steps concern the decomposition of $\mathrm{AlNaH}_{4}$ and $\mathrm{AlNa}_{3} \mathrm{H}_{6}$ which is not affected by $\mathrm{MgNaH}_{3}$.

Ismail et al. [9] compared the hydrogen storage properties of $4 \mathrm{MgH}_{2}+\mathrm{AlNaH}_{4}$ and those of $4 \mathrm{MgH}_{2}+-$ $\mathrm{AlNa}_{3} \mathrm{H}_{6}$ mixtures. The TPD curves [9] show that both composites start to decompose at around $170{ }^{\circ} \mathrm{C}$, which is 10 and $55^{\circ} \mathrm{C}$ lower than the decomposition temperature of the as-milled $\mathrm{AlNaH}_{4}$ and $\mathrm{AlNa}_{3} \mathrm{H}_{6}$, respectively. For this reason, Ismail et al. [9] concluded that the $\mathrm{MgH}_{2}+$ $\mathrm{AlNa}_{3} \mathrm{H}_{6}$ composite is better than the $\mathrm{MgH}_{2}+\mathrm{AlNaH}_{4}$ composite. However, according to our calculations, there is no difference in the decomposition process of the two composites and the mutual destabilization of $\mathrm{MgH}_{2}$ and $\mathrm{AlNaH}_{4} / \mathrm{AlNa}_{3} \mathrm{H}_{6}$ hydrides in this composition range $\left(4 \mathrm{MgH}_{2}+\mathrm{AlNa}_{3} \mathrm{H}_{6}\right.$, when the number of $\mathrm{Mg}$ atoms exceeds the number of $\mathrm{Na}$ atoms) does not depend on the hydrides' decomposition temperatures.

\section{Conclusion}

In this work, thermodynamic modeling is used to investigate the reaction mechanisms and hydrogen storage properties in the $\mathrm{Al}-\mathrm{Mg}-\mathrm{Na}-\mathrm{H}$ system. A self-consistent database has been constructed by extrapolating the different binaries assessed in this work or taken from the literature, using the CALPHAD method.

The reaction pathways for the reaction $\mathrm{MgH}_{2} / \mathrm{AlH}_{3}$, $\mathrm{MgH}_{2} / \mathrm{NaAlH}_{4}$, and $\mathrm{MgH}_{2} / \mathrm{Na}_{3} \mathrm{AlH}_{6}$ are calculated and show good agreement with experimental data from the literature and provide insight regarding the reaction temperatures, the amount of the products, and their composition. It is shown that $\mathrm{Al}$ destabilizes $\mathrm{MgH}_{2}$ by the formation of $\mathrm{Al}-\mathrm{Mg}$ solid solutions and compounds. This process depends on $\mathrm{Al}$ content. The first step decomposition temperature of $\mathrm{MgH}_{2}$ in the mixture at 1 bar is $234^{\circ} \mathrm{C}$; i.e., $50.73{ }^{\circ} \mathrm{C}$ lower than the decomposition temperature of $\mathrm{MgH}_{2}$ alone and is due to the formation of the $\beta$ phase. The calculated pressure-composition isotherms for Mg-10 at $\%$ $\mathrm{Al}$ and Mg-4 at\% $\mathrm{Al}$ alloys at $350{ }^{\circ} \mathrm{C}$ show good agreement with the experimental data and give a more detailed description of the hydriding process products and equilibrium pressures. These calculations explain the uncertainties found in the literature, especially the sloping curves and difficult plateau pressures distinction. It is shown that the first hydrogenation of $\mathrm{Al}-\mathrm{Mg}$ alloys starts at higher pressure than pure $\mathrm{Mg}$ and depends on the $\mathrm{Al}$ content. In fact, for $\mathrm{Al}$ content higher than 7 at $\%$, the hydrogenation of hcp$\mathrm{Mg}$ occurs in one step with the formation of the $\gamma$ phase at 6.26 bar. However, for Al content lower than 7 at $\%$, the hcp-Mg is hydrogenated first at pressures increasing with $\mathrm{Al}$ content (5.84 bar for pure $\mathrm{Mg}$ to 6.26 bar for 7 at\% $\mathrm{Al}$ in $\mathrm{Mg}$ alloy) and is related to the solubility of $\mathrm{Al}$ in hcp$\mathrm{Mg}$, followed by the formation of the $\gamma$ phase at $6.26 \mathrm{bar}$. It is shown that the PCIs sloping reported in the literature for the $\mathrm{Al}-\mathrm{Mg}$ alloys is, in addition to kinetic factors, due to the large solubility of the $\gamma$ phase, to short plateaus' length, and to the small differences between plateau pressures.

For $\mathrm{MgH}_{2} / \mathrm{NaAlH}_{4}$ and $\mathrm{MgH}_{2} / \mathrm{Na}_{3} \mathrm{AlH}_{6}$, it is shown that reaction mechanisms in the composites depend on the relative amount of the components. It is demonstrated that each component of the composite destabilizes the other component in a specific composition range by the formation of $\mathrm{NaMgH}_{3}$. When the number of $\mathrm{Mg}$ atoms in the $\mathrm{MgH}_{2}+\mathrm{AlNaH}_{4} / \mathrm{AlNa}_{3} \mathrm{H}_{6}$ mixture exceeds the number of $\mathrm{Na}$ atoms, all the $\mathrm{AlNaH}_{4} / \mathrm{AlNa}_{3} \mathrm{H}_{6}$ decomposes spontaneously and the remaining decomposition steps concern the decomposition of $\left(\mathrm{MgH}_{2}+\mathrm{Al}\right)$ mixture and $\mathrm{MgNaH}_{3}$ acts only as a catalyst.

When the number of $\mathrm{Na}$ atoms in $\mathrm{MgH}_{2}+\mathrm{AlNaH}_{4} /$ $\mathrm{AlNa}_{3} \mathrm{H}_{6}$ mixture exceeds the number of $\mathrm{Mg}$ atoms, $\mathrm{MgH}_{2}$ decomposes spontaneously and the remaining steps concern the decomposition of $\mathrm{AlNaH}_{4}$ and $\mathrm{AlNa}_{3} \mathrm{H}_{6}$, which is not affected by $\mathrm{MgNaH}_{3}$ that might have a catalytic effect on the process. $\mathrm{MgNaH}_{3}$ in this mixture decomposes to form the $\beta$ phase at $331{ }^{\circ} \mathrm{C}$, i.e., $51.6{ }^{\circ} \mathrm{C}$ lower than the decomposition temperature of pure $\mathrm{MgNaH}_{3}$.

Open Access This article is distributed under the terms of the Creative Commons Attribution 4.0 International License (http:// creativecommons.org/licenses/by/4.0/), which permits unrestricted use, distribution, and reproduction in any medium, provided you give appropriate credit to the original author(s) and the source, provide a link to the Creative Commons license, and indicate if changes were made.

\section{References}

1. Sakintuna, B., Lamari-Darkrim, F., Hirscher, M.: Metal hydride materials for solid hydrogen storage: a review. Int $\mathrm{J}$ Hydrog Energy 32, 1121-1140 (2007)

2. Abdessameud, S., Mezbahul-Islam, M., Medraj, M.: Thermodynamic modeling of hydrogen storage capacity in $\mathrm{Mg}-\mathrm{Na}$ alloys. Sci. World J. 2014, ID 190320 (2014). doi:10.1155/2014/190320

3. Bogdanović, B., Schwickardi, M.: Ti-doped alkali metal aluminium hydrides as potential novel reversible hydrogen storage materials. J. Alloys Compd. 253, 1-9 (1997)

4. Qiu, C., Opalka, S.M., Olson, G.B., Anton, D.L.: Thermodynamic modeling of the sodium alanates and the Na-Al-H system. Zeitschrift Für Metallkunde 97, 1484-1494 (2006)

5. Tanniru, M., Slattery, D.K., Ebrahimi, F.: A study of stability of $\mathrm{MgH}_{2}$ in $\mathrm{Mg}-8$ at\% $\mathrm{Al}$ alloy powder. Int. J. Hydrog. Energy 35, 3555-3564 (2010)

6. Tanniru, M., Slattery, D.K., Ebrahimi, F.: A study of phase transformations during the development of pressure-compositionisotherms for electrodeposited $\mathrm{Mg}-\mathrm{Al}$ alloys. Int. J. Hydrogen Energy 36(1), 639-647 (2011)

7. Ismail, M., Zhao, Y., Yu, X., Mao, J., Dou, S.: The hydrogen storage properties and reaction mechanism of the $\mathrm{MgH}_{2}-\mathrm{NaAlH}_{4}$ composite system. Int. J. Hydrogen Energy 36, 9045-9050 (2011) 
8. Ismail, M., Zhao, Y., Yu, X., Dou, S.: Improved hydrogen storage performance of $\mathrm{MgH}_{2}-\mathrm{NaAlH}_{4}$ composite by addition of $\mathrm{TiF}_{3}$. Int. J. Hydrogen Energy 37, 8395-8401 (2012)

9. Ismail, M., Zhao, Y., Dou, S.: An investigation on the hydrogen storage properties and reaction mechanism of the destabilized $\mathrm{MgH}_{2}-\mathrm{Na}_{3} \mathrm{AlH}_{6}$ (4:1) system. Int. J. Hydrogen Energy 38, 1478-1483 (2013)

10. Liu, H., Wang, X., Liu, Y., Dong, Z., Cao, G., Li, S., Yan, M.: Improved hydrogen storage properties of $\mathrm{MgH}_{2}$ by ball milling with $\mathrm{AlH}_{3}$ : preparations, de/rehydriding properties, and reaction mechanisms. J. Mater. Chem. A 1, 12527-12535 (2013)

11. Liu, H., Wang, X., Liu, Y., Dong, Z., Ge, H., Li, S., Yan, M.: Hydrogen desorption properties of the $\mathrm{MgH}_{2}-\mathrm{AlH}_{3}$ composites. J. Phys. Chem. C 118, 37-45 (2014)

12. Bale, C., Pelton, A., Thompson, W.: FactSage 6.4, Factsage thermochemical software and databases (2013). http://www.crct. polymtl.ca/.

13. Qiu, C., Olson, G.B., Opalka, S.M., Anton, D.L.: Thermodynamic evaluation of the Al-H system. J. Phase Equilib. Diffus. 25, 520-527 (2004)

14. Harvey, J.: Developpement d'une base de donnees thermodynamique pour la modelisation de la solubilite d'hydrogene dans les alliages d'aluminium. Thesis, Ecole Polytechnique, Montreal, Canada, M.Sc.A., (2007)

15. Harvey, J.P., Chartrand, P.: Modeling the hydrogen solubility in liquid aluminum alloys. Metall. Mater. Trans. B 41B, 908-924 (2010)

16. San-Martin, A., Manchester, F.: The al-H (aluminum-hydrogen) system. J. Phase Equilib. 13, 17-21 (1992)

17. Graetz, J., Reilly, J., Yartys, V., Maehlen, J., Bulychev, B., Antonov, V., Tarasov, B., Gabis, I.: Aluminum hydride as a hydrogen and energy storage material: past, present and future. J. Alloys Compd. 509, S517-S528 (2011)

18. Murray, J.L.: The Al-Na (Aluminum-Sodium) system. J. Phase Equilib. 4, 407-410 (1983)

19. Zhang, S., Han, Q., Liu, Z.: Thermodynamic modeling of the AlMg-Na system. J. Alloys Compd. 419, 91-97 (2006)

20. Scheuber, E.: Study of the solubility of sodium in aluminum. Z. Metallkd. 27, 83-85 (1935)

21. Fink, W., Willey, L., Stumpf, H.: Equilibrium relations in aluminum-sodium alloys of high purity. Trans AIME 175, 364-371 (1948)

22. Ransley, C.E., Neufeld, H.: The solubility relationships in the aluminum-sodium and aluminum-silicon-sodium systems. J. Inst. Met. 78, 25-46 (1950)

23. Hansen, S., Tuset, J., Haarberg, G.: Thermodynamics of liquid Al-Na alloys determined by using $\mathrm{CaF}_{2}$ solid electrolyte. Metall. Mater. Trans. B 33(4), 577-587 (2002)

24. Fellner, P., Korenko, M., Danielik, V., Thonstad, J.: The content of sodium in aluminium during electrolysis of the molten systems $\mathrm{Na} 3 \mathrm{AlF}_{6}-\mathrm{NaCl}-\mathrm{Al}_{2} \mathrm{O}_{3}$ and $\mathrm{NaF}-\mathrm{NaCl}$. Electrochim. Acta 49, 1505-1511 (2004)

25. Dewing, E.: Thermodynamics of system $\mathrm{NaF}_{-} \mathrm{AlF}_{3}$. 3. Activities in liquid mixtures. Metall. Trans. 3, 495-501 (1972)

26. Brisley, R., Fray, D.: Determination of the sodium activity in aluminum and aluminum silicon alloys using sodium beta alumina. Metall. Trans. B 14, 435-440 (1983)

27. Rokhlin, L., Ivanchenko, V.: Al-H-Mg. In: Effenberg, G., Ilyenko, S. Effenberg, S.I.G. (eds.) Light metal ternary systems: phase diagrams, crystallographic and thermodynamic data, vol. 11A3, pp. 64-70. Springer-Verlag Berlin Heidelberg, Germany (2005)

28. Baukloh, W., Oesterlen, F.: The solubility of hydrogen in aluminum and some aluminum alloys. Z. Metallkd. 30, 386-389 (1938)
29. Chernega, D.F., Gotvyanskii, Y.Y., Prisyazhnyuk, T.N.: Permeability, diffusion and solubility of $\mathrm{H}$ in $\mathrm{Mg}-\mathrm{Al}$ alloys. Liteinoe Proizvod. 12, 9-10 (1977)

30. Watanabe, T., Tachihara, Y., Huang, Y., Komatsu, R.: Effects of various alloying elements on the solubility of $\mathrm{H}$ in $\mathrm{mg}$. J. Jpn. Inst. Light Metals 26(4), 167-174 (1976)

31. Huang, Y.C., Watanabe, T., Komatsu, R.: Hydrogen in magnesium and its alloys. In: Proceedings of the 4th international conference on vacuum Metallurgy, pp. 176-179 (1974)

32. Øvrelid, E., Engh, T.A., Øymo, D.: vol. PA, pp. 771-78. Light Metals, TMS, Warrendale (1994)

33. Semenenko, K.N., Verbettskii, V.N., Kotchukov, A.V., Sytnikov, A.N.: Reaction of magnesium containing intermetallic compounds and alloys with hydrogen. Vestn. Mosk. Uni. Ser. 2 Khim 24, 16-27 (1983)

34. Palumbo, M., Torres, F., Ares, J., Pisani, C., Fernandez, J., Baricco, M.: Thermodynamic and ab initio investigation of the Al-H-Mg system. Calphad 31, 457-467 (2007)

35. Grove, H., Løvvik, O.M., Huang, W., Opalka, S.M., Heyn, R.H., Hauback, B.C.: Decomposition of lithium magnesium aluminum hydride. Int. J. Hydrog. Energy 36, 7602-7611 (2011)

36. Mamatha, M., Bogdanović, B., Felderhoff, M., Pommerin, A., Schmidt, W., Schüth, F., Weidenthaler, C.: Mechanochemical preparation and investigation of properties of magnesium, calcium and lithium-magnesium alanates. J. Alloys Compd. 407(1), 78-86 (2006)

37. Varin, R., Chiu, C., Czujko, T., Wronski, Z.: Mechano-chemical activation synthesis (MCAS) of nanocrystalline magnesium alanate hydride $\left[\mathrm{mg}\left(\mathrm{AlH}_{4}\right)_{2}\right]$ and its hydrogen desorption properties. J. Alloys Compd. 439(1), 302-311 (2007)

38. Kim, Y., Lee, E., Shim, J., Cho, Y.W., Yoon, K.B.: Mechanochemical synthesis and thermal decomposition of $\mathrm{mg}$ $\left(\mathrm{AlH}_{4}\right)_{2}$. J. Alloys Compd. 422(1), 283-287 (2006)

39. Iosub, V., Matsunaga, T., Tange, K., Ishikiriyama, M.: Direct synthesis of $\mathrm{mg}\left(\mathrm{AlH}_{4}\right)_{2}$ and $\mathrm{CaAlH}_{5}$ crystalline compounds by ball milling and their potential as hydrogen storage materials. Int. J. Hydrog. Energy 34(2), 906-912 (2009)

40. Sterlin Leo Hudson, M., Pukazhselvan, D., Irene Sheeja, G., Srivastava, O.: Studies on synthesis and dehydrogenation behavior of magnesium alanate and magnesium-sodium alanate mixture. Int. J. Hydrog. Energy 32(18), 4933-4938 (2007)

41. Liu, Y., Pang, Y., Zhang, X., Zhou, Y., Gao, M., Pan, H.: Synthesis and hydrogen storage thermodynamics and kinetics of $\mathrm{Mg}\left(\mathrm{AlH}_{4}\right)_{2}$ submicron rods. Int. J. Hydrog. Energy 37(23), 18148-18154 (2012)

42. Mintz, M., Gavra, Z., Kimmel, G., Hadari, Z.: The reaction of hydrogen with magnesium alloys and magnesium intermetallic compounds. J. Less Common Metals 74(2), 263-270 (1980)

43. Gavra, Z., Hadari, Z., Mintz, M.: Effects of nickel and indium ternary additions on the hydrogenation of $\mathrm{Mg}$ - $\mathrm{Al}$ intermetallic compounds. J. Inorg. Nucl. Chem. 43(8), 1763-1768 (1981)

44. Zaluska, A., Zaluski, L., Ström-Olsen, J.: Structure, catalysis and atomic reactions on the nano-scale: a systematic approach to metal hydrides for hydrogen storage. Appl. Phys. A 72, 157-165 (2001)

45. Shang, C., Bououdina, M., Song, Y., Guo, Z.: Mechanical alloying and electronic simulations of $\left(\mathrm{MgH}_{2}-\mathrm{M}\right)$ systems $(\mathrm{M}=\mathrm{Al}, \mathrm{Ti}, \mathrm{Fe}, \mathrm{Ni}, \mathrm{Cu}$ and $\mathrm{Nb})$ for hydrogen storage. Int. J. Hydrogen Energy 29, 73-80 (2004)

46. Andreasen, A.: Hydrogenation properties of $\mathrm{Mg}-\mathrm{Al}$ alloys. Int. J. Hydrogen Energy 33, 7489-7497 (2008)

47. Nakamori, Y., Ninomiya, A., Kitahara, G., Aoki, M., Noritake, T., Miwa, K., Kojima, Y., Orimo, S.: Dehydriding reactions of mixed complex hydrides. J. Power Sour. 155(2), 447-455 (2006)

48. Sartori, S., Qi, X., Eigen, N., Muller, J., Klassen, T., Dornheim, M., Hauback, B.C.: A search for new Mg- and K-containing 
alanates for hydrogen storage. Int. J. Hydrogen Energy 34(5), 4582-4586 (2009)

49. Dinsdale, A.T.: SGTE data for pure elements. Calphad 15(4), 317-425 (1991)

50. Ransley, C., Talbot, D.: Hydrogen porosity in metals with special reference to aluminum and its alloys. Z. Metallkd. 46(5), 328-337 (1955)

51. Hemmes, H., Driessen, A., Griessen, R.: Thermodynamic properties of hydrogen at pressures up to 1 Mbar and temperatures between 100 and 1000K. J. Phys. C Solid State Phys. 19, 3571 (1986)
52. Dewing, E.W.: Thermodynamics of the system $\mathrm{NaF}_{-} \mathrm{AlF}_{3}$ : part VI. Revision. Metall. Trans. B 21(2), 285-294 (1990)

53. Claudy, P., Bonnetot, B., Letoffe, J.: Preparation and physicochemical properties of magnesium alanate. J. Therm. Anal. 15, 119-128 (1979)

54. Bouaricha, S., Dodelet, J., Guay, D., Huot, J., Boily, S., Schulz, R.: Hydriding behavior of $\mathrm{Mg}-\mathrm{Al}$ and leached $\mathrm{Mg}-\mathrm{Al}$ compounds prepared by high-energy ball-milling. J. Alloys Compd. 297(1), 282-293 (2000) 